\title{
What happened when the Pleistocene megafauna became extinct?
}

\author{
Laura Miotti $^{\text {a, * }}$, Eduardo Tonni ${ }^{\text {b }}$, Laura Marchionni ${ }^{\text {a }}$ \\ a CONICET/ División Arqueología, Facultad de Ciencias Naturales y Museo-UNLP, FCNyM-UNLP, Argentina \\ ${ }^{\mathrm{b}}$ Museo de La Plata, Facultad de Ciencias Naturales y Museo- UNLP, FCNyM-UNLP, Argentina
}

\section{A R T I C L E I N F O}

\section{Article history:}

Received 26 October 2016

Received in revised form

27 December 2017

Accepted 6 January 2018

\section{Keywords:}

End Pleistocene

Massive extinctions

Pampa-Patagonia

Human agency

\begin{abstract}
A B S T R A C T
This work presents an updated revision of the information about Pleistocene fauna records in archeological sites of the Pampa and Patagonian regions of South America. The purpose is to assess the role played by humans within the extinction process of Pleistocene mammals in the South Cone and the effects that the disappearance of Pleistocene large mammals had in human populations which colonized both regions. This is based on the theory of "Broken Zig-Zag", which considers that the process was gradual in time and in different species, taking place between $15 \mathrm{Ka}$ BP and $8.5 \mathrm{Ka}$ BP in Patagonia and during a longer period, until ca. 7.5 Ka BP in Pampa. For this aim it was considered all those sites with accurate chronological and taxonomic information about the presence of extinct species of mega and large mammals of xenarthrans, camelids, equids and carnivores. Thus, the work is focused on three analytical lines: regional analysis of radiocarbon records of first and last taxonomic appearance, ecology and etiology of species with archeological record and variability of associations of the archaeofauna with material culture. We discuss how the first humans took possession of Pampa and Patagonian regions during and after the last part of the continental extinction process. Thus, there is a contribution with new hypotheses about the differential use of the extinct fauna in both regions. This interdisciplinary approach of social and environmental agency has not been considered in the specialized bibliography so far; therefore novel information is given for interpreting the way in which humans took possession of the fauna, not only as subsistence resources but also as other important agents in the socio-economic and symbolic relationship of humans with the landscape. On the whole, the final result is that the gregarious species of large herbivores (camelids) were the most important resources for hunter-gatherers from the beginning of human colonization. The extinct fauna influenced subsistence complementarily, though it played an important role in the social and symbolic spheres.
\end{abstract}

๑) 2018 Elsevier Ltd and INQUA. All rights reserved.

\section{Introduction}

The extinction of Pleistocene megafauna and other large and small mammals in America is a topic that has already been discussed academically for more than a century regarding the factor(s) which produced such process. The main ideas were being outlined dissimilarly about the role the first humans played in such extinctions when they entered the new world. In the last years, the most widely accepted hypothesis is that the finipleistocenic extinctions are considered as a process of deep changes, temporarily long and environmentally heterogeneous, where the human impact about the faunas was collateral.

On the other hand, every new archaeological finding referred to

\footnotetext{
* Corresponding author.

E-mail address: laura.miotti2@gmail.com (L. Miotti).
}

that period of time introduces new questions about the level of human-fauna interaction in such a complex process that began operating at the end of the Pleistocene and that in some regions like Pampa, lasted until mid Holocene (Martínez and Gutiérrez, 2011; Martínez et al., 2016). The main role given to humans in the extinction process was due to findings of large sites of mammoth and bison slaughter that, since the first decades of the 20th century, have been carried out in North America. Thus, the scenario and role of the first settlers in the continent may have been magnified as regards the excessive hunting of mega and large mammals, with the minimization of the small species hunting and recollection of animal and vegetable products (Sellards et al., 1947; Wormington, 1957). In this sense, and together with the progression of a programme of systematic archaeological excavations in sites of first Americans from the great North America plateaus, in the 1970s the main ideas about human-megafauna interactions were stemmed in three hypothesis lines: 1) That of an intensive human exploitation 
of the Pleistocene fauna which provoked the fast extinction by "Overkill or blitzkrieg" (Martin, 1973, 2005), here the humans could have been the main cause of extinctions; 2) a scenario of scarce interaction of humans hunting those mega faunas, and where it is understood that the deep postglacial environmental changes were mainly responsible for the fauna extinctions (Bryan, 1978; Guthrie, 1984). Finally, 3) where the humans may have been another factor in the extinction process but not the main one. Their role could have been that of a catalyst or "coup de grace" that boosted the extinction of animal populations that, due to environmental changes at the end of Pleistocene, were already in clear numerical regression (Guilday, 1984; Miotti and Salemme, 1999; Cione et al., 2009; Metcalf et al., 2016).

More thorough studies and in more extended regions in South America allow highlighting another observation, presented by Alan Bryan $(1986,1995)$ but dodged by many, which lies on the principle of the huge environmental and cultural variability of the end of the Pleistocene in North and South America. This key idea made us redirect our exploration to the southern portion of the continent and thus formulate new ideas about the ways in which the first humans explored, got in contact with the great variety of environments in South America and finally, colonized the continent (Miotti, 2003; Miotti and Marchionni, 2012). Now, in the light of new paleo-environmental and archeological information, the most moderated hypothesis to explain the scenario of mega-mammal and large mammal extinction in South America, close to the Pleistocene-Holocene transition, seems to be that summarized in the "Broken Zig-Zag" theory (Cione et al., 2003, 2009, 2015; Prado et al., 2015; Metcalf et al., 2016; Politis et al., 2016).

This is based on the special fauna structure of South America, stemmed partly from the impact produced by the Great American Biotic Interchange (GABI); its confirmation was obtained from Pampa archeological sites towards Pleistocene and beginning of Holocene, which present a prevalence of xenarthrans in the megafauna; the scarce representation of the total diversity of the extinct mega-mammals and large mammals in the archeological sites, and in short the extinct mega-mammals and large mammals are part of GABI in South America. In this background Cione (Cione et al., 2009) consider that humans participated in the GABI, but they were not the main actors. In this sense, this hypothesis is in concordance with our works in Pampa and Patagonia (Miotti, 1998; Miotti and Salemme, 1999, 2004; Miotti and Marchionni, 2012; Salemme, 2014).

In those works, we proposed that the first settlers of Pampa and Patagonia could have had a generalized or broad spectrum huntinggathering strategy, and that at the end of the early Holocene and at the beginning of Holocene they could have started to change it towards a specialized one, mainly based on the exploitation of the species Lama guanicoe (guanaco) (Miotti and Salemme, 1999). In the light of the information that is presented herein, it is perceived that such change could have happened previously, when Pampa and Patagonia peopling was still in early development. Therefore, in this work we carry out an updated and re-assessed summary of the available information about the record of Pleistocene species, whose survival until early Holocene allows suggesting a longer use of some species in both regions aforementioned. In this case, even though the environmental changes must have been of great impact in each region for the disappearance of mega-mammals, the purpose of this work is to approach new ideas about the kind of appropriation performed by human groups and as a consequence, to bring up for discussion the human impact about extinctions. To achieve these objectives, the contextual archaeofauna and archeological information has been brought into play. This information allows better understanding of the social and symbolic impact, beyond that ecological and economic of the humans who colonized Pampa and Patagonia. In that sense, this new information contributes to re-assess the hypothesis about the megafauna extinction and its environmental and social consequences in Pampa and Patagonia, to support the variability of forms that this process had in different latitudes, and finally, to evaluate humanmegafauna interactions and the impact that its disappearance had in different regions for the first settlers, not only in terms of economic resources but also social and symbolic resources.

\section{Background and methodology}

The reference framework used here is that of zooarcheology, taphonomy and biogeography of updating basis and regional scale. These parameters are the most suitable for the data analysis necessary for drafting the relationship trends between the first humans and faunas, as well as the concept of changes of human appropriation in different paleo-environmental scenarios. Both in Pampa and Patagonia the advances produced in the paleoenvironmental reconstruction, either from the study of archaeofaunas or from several environmental proxy, and from the use that humans made of the fauna resources, have been outstanding in the last decades. However, in order to delve into the ways huntergatherers developed for appropriating new resources, it has also been considered the ethology and ecology of species with archeological record and corresponding to Lujanian fauna ( $40 \mathrm{Ka}^{1} \mathrm{BP}$ to 7.5 Ka BP).

The study of the recorded species behavior is an important tool for relating the trends of the use of different weapons and hunting strategies (collective or solitary; by encounter or by lurking). In that sense, the assumption is that the most recurrent species in the archeological sites were those that fitted most the hunting techniques. For defining the use or human coexistence with different species throughout the transition Pleistocene-Holocene and early Holocene, the dates of the first and last appearance of the main Pleistocene mammals with archeological record were considered.

The selected sites are grouped in four time blocks (Fig. 1 and Tables $1 \mathrm{a}, \mathrm{b}$ and 2 ) that involve the contexts of hunter-gatherer societies populating both regions during the "Colonization" phase (13-8.5 Ka BP), which includes "scouting" and choice of new environments for inhabiting (Meltzer, 2003; Rockman, 2003; Miotti, 2008; Miotti et al., 2015), and the "Territorial consolidation" phase (8.5-4.5 Ka BP) sensuMiotti (2003) and Miotti and Salemme (1999, 2004); or colonization phase sensuBorrero (1990).

Calculations of taxonomic diversity/abundance with the purpose at evaluate the use of fauna in both regions was carried out based on a Ntaxa of each site. This is due to the fact that NISP values are only available for some of the researched contexts, and therefore, even though the production of more specific abundance indexes such as diversity $(\mathrm{d} 1)$, and richness $\left(\mathrm{H}^{\prime}\right)$ indexes (Grayson, 1984) would provide a better definition to tendencies, data quantification in this parameter becomes very heterogeneous in different sites of both regions. Finally, to evaluate the social and symbolic impact that the disappearance of large mammals and mega-mammals could have had among the first settlers, contextual archaeological markers were taken beyond the zooarchaeological data. These are rock art as well as specimens of special anatomic portions of certain animals, such as paws and teeth of large carnivores, scutes of glyptodonts and leather of mylodonts (Taçon et al., 1996; Politis and Saunders, 2002; Miotti and Carden, 2007).

For this work it has been chosen 45 zooarcheological contexts of Pampa and Patagonian (Chilean and Argentinian) regions, whose human settlements correspond to the transition Pleistocene-

\footnotetext{
${ }^{1} \mathrm{Ka} \mathrm{BP}$ is considered in ${ }^{14} \mathrm{C}$ years before present.
} 


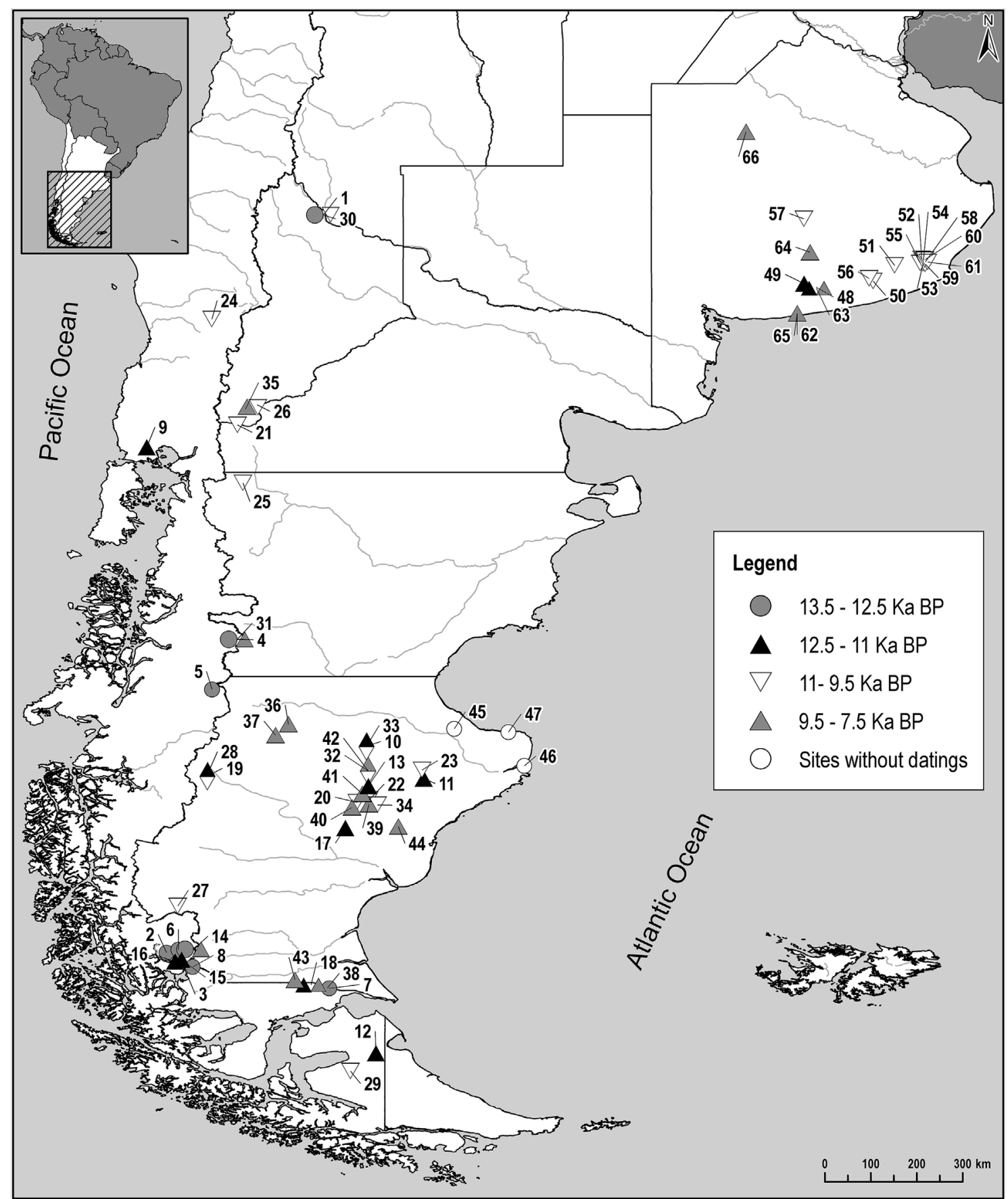

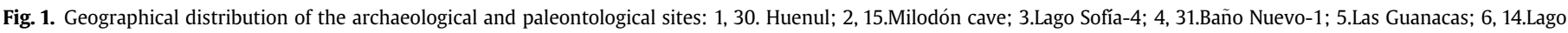

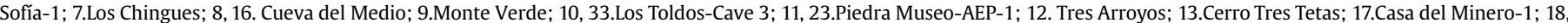

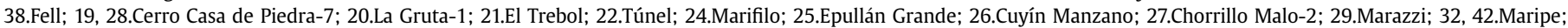

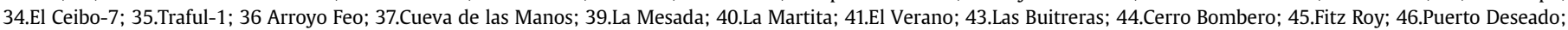

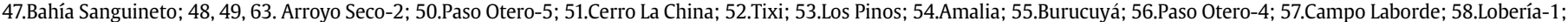
59.Los Helechos; 60.El Abra; 61. La Brava; 62, 65.El Guanaco; 64.La Moderna; 66.Laguna de los Pampas.

Holocene, early Holocene and mid Holocene (Fig. 1 and Tables 1 and 2 ), and where remains of Pleistocene fauna have been found.

\section{The great biotic interchange. Implications of the holartic species in Pleistocene extinctions in South America}

Around three million years ago, when the terrestrial bridge between North America and South America was linked (Cione et al.
2015), the last stage of the great biotic interchange between North American and South American subcontinents took place (GABI). During this interchange, numerous mammal families of the Holarctic Region emigrated to South America. The immigrant mega mammals (heavier than 1 ton) were only the Gomphoterids, while the large mammals (heavier than $44 \mathrm{~kg}$ ) included ursids, tayassuids, equids, camelids and cervids, among other felids (Cione et al., 2009). Regarding the native fauna from South America, xenarthrans 
Table 1

Frequencies of extinct and living mammals at archaeological sites in Patagonia region.

\begin{tabular}{|c|c|c|c|c|c|c|}
\hline \multirow{2}{*}{$\overline{\#}$} & \multirow{2}{*}{$\begin{array}{l}\text { PATAGONIA sites showed in Fig. } 1 \\
\text { Name }\end{array}$} & \multirow[t]{2}{*}{${ }^{14} \mathrm{C}$ dating } & \multicolumn{3}{|c|}{ Frequencies of species } & \multirow[t]{2}{*}{ References } \\
\hline & & & living & extinct & total Nsp & \\
\hline 1 & Huenul cave & $13,840 \pm 56-11,841 \pm 56$ & 1 & 1 & 2 & Barberena et al., 2015, Pompei et al., 2012 \\
\hline 2 & Milodón cave & $13,630 \pm 50-12,000 \pm$ & 1 & 5 & 6 & Martin, 2013 \\
\hline 3 & Lago Sofía 4 cave & $13,400 \pm 90-11,590 \pm 100$ & 8 & 5 & 13 & Martin, 2013 \\
\hline 4 & Baño Nuevo 1 cave & $13,480 \pm 35-11,240 \pm 40$ & 1 & 2 & 3 & Mena and Reyes, 2001 \\
\hline 5 & Las Guanacas rockshelter & $13,275 \pm 50$ & 3 & 5 & 8 & Labarca et al., 2008; \\
\hline 6 & Lago Sofía 1 cave & $12,990+490$ & 1 & 2 & 3 & Borrero et al., 1997 \\
\hline 7 & Los Chingues cave & $12,165+80$ & 1 & 3 & 4 & Martin, 2013 \\
\hline 8 & Cueva del Medio & $12,720 \pm 300$ & 1 & 1 & 2 & Nami and Nakamura, 1995 \\
\hline 9 & Monte Verde & $12,500_{ \pm}-11,800_{ \pm}$ & 2 & 3 & 5 & Dillehay, 1997 \\
\hline 10 & Los Toldos cave 3 layer 11 & $12,600 \pm 650-$ ca. 11,000 & 3 & 2 & 5 & Cardich, 1987 \\
\hline 11 & Piedra Museo AEP-1 layer 6 & $12,890 \pm 60-11,000 \pm 50$ & 3 & 4 & 7 & Miotti et al., 1999; 2003 \\
\hline 12 & Tres Arroyos rockshelter & $11,880 \pm 250-10,280 \pm 110$ & 4 & 3 & 7 & Massone, 2003 \\
\hline 13 & Cerro Tres Tetas cave & $11,575 \pm 140-10,260 \pm 110$ & 1 & 0 & 1 & Paunero, 2000, 2003 \\
\hline 14 & Lago Sofía 1 cave & $11,560 \pm 70-10,300 \pm 40$ & 4 & 3 & 7 & Martin, 2013 \\
\hline 15 & Milodón cave & $11,330_{ \pm}^{*}-10,200_{ \pm}^{*}$ & 1 & 2 & 3 & Borrero and Martin, 2012 \\
\hline 16 & Cueva del Medio & $11,120 \pm 130-10,310 \pm 70$ & 5 & 3 & 8 & Nami and Nakamura, 1995 \\
\hline 17 & Casa del Minero I cave & $11,000 \pm 55-10,970 \pm 55$ & 1 & 3 & 4 & Paunero et al., 2007 \\
\hline 18 & Fell cave & $11,000 \pm 160-10.720 \pm 300$ & 5 & 3 & 8 & Bird, 1988 \\
\hline 19 & Cerro Casa de Piedra 7 (CCP 7) & $10,690 \pm-10,530 \pm 620$ & 1 & 1 & 2 & De Nigris, 2004 \\
\hline 20 & La Gruta 1 cave & $10,845 \pm 61-10,400 \pm 50$ & 1 & 0 & 1 & Franco et al., 2010 \\
\hline 21 & El Trébol rockshelter & $10,600 \pm 100-10,570 \pm 130$ & 15 & 2 & 17 & Hajduk et al., 2012 \\
\hline 22 & La María, Túnel cave & $10,510_{ \pm}-10,400 \pm 100$ & 6 & 4 & 10 & Paunero et al., 2007, 2010 \\
\hline 23 & AEP1- layer $4 / 5$ & $10.470 \pm 65-9230 \pm 105$ & 3 & 2 & 5 & Miotti et al., 2003 \\
\hline 24 & Marifilo rockshelter 1 & $10,410 \pm 70-8420 \pm 40$ & 2 & 0 & 2 & Mera and García 2004 \\
\hline 25 & Epullán Grande cave & $9970 \pm 100-7550 \pm 70$ & 1 & 7 & 8 & Cordero, 2011 \\
\hline 26 & Cuyín Manzano cave & $9920 \pm 240$ & 3 & 0 & 3 & Cordero, 2011 \\
\hline 27 & Chorrillo Malo-2 & $9740 \pm 50-9690 \pm 80$ & 1 & 0 & 1 & Franco and Borrero, 2003 \\
\hline 28 & Cerro Casa de Piedra 7 (CCP7) rockshelter & $9730 \pm 100-8300 \pm 115$ & 7 & 0 & 7 & De Nigris, 2004 \\
\hline 29 & Marazzi rockshelter & $9590 \pm 210$ & 1 & 1 & 2 & Morello et al., 1999 \\
\hline 30 & Huenul cave unit IV & $10,155 \pm 98-9261 \pm 66$ & 2 & 0 & 2 & Barberena et al., 2015 \\
\hline 31 & Baño Nuevo 1 cave & $9530 \pm 25-8530 \pm 160$ & 2 & 0 & 2 & Mena et al., 2003 \\
\hline 32 & Maripe cave & $9518 \pm 64-7153 \pm 50$ & 3 & 0 & 3 & Miotti et al., 2007, 2014 \\
\hline 33 & Los Toldos cave 3 , layers 9 and 8 & ca. $9500-8750 \pm 480$ & 5 & 2 & 7 & Cardich, 1987 \\
\hline 34 & El Ceibo 7 rockshelter, layer 12 & ca. 9500 & 5 & 1 & 6 & Miotti and Salemme, 1999 \\
\hline 35 & Traful 1 cave & $9430 \pm 230-9285 \pm 105$ & 1 & 0 & 1 & Cordero, 2011 \\
\hline 36 & Arroyo Feo cave & $9410 \pm 70-8410 \pm 70$ & 8 & 0 & 8 & Silveira, 1979 \\
\hline 37 & Cueva de Las Manos & $9320 \pm 90-9300 \pm 90$ & 7 & 0 & 7 & Mengoni Goñalons and Silveira, 1976 \\
\hline 38 & Fell Cave & $10,080 \pm 160-9100 \pm 70$ & 1 & 0 & 1 & Bird, 1988 \\
\hline 39 & La Mesada cave & $9090 \pm 40$ & 2 & 0 & 2 & Paunero et al., 2007 \\
\hline 40 & La Martita cave & $8050 \pm 90-7940 \pm 260$ & 2 & 0 & 2 & Aguerre, 2003 \\
\hline 41 & El Verano cave & $8960 \pm 140-7500 \pm 250$ & 3 & 3 & 6 & Durán, 1986/1987 \\
\hline 42 & Maripe cave, layer 4 & $88270 \pm 87-8012 \pm 80$ & 2 & & 2 & Miotti et al., 2014 \\
\hline 43 & Las Buitreras cave layer VII & CA. 9000 & 1 & 2 & 3 & Sanguinetti, 1976 \\
\hline 44 & Cerro Bombero & ca. 8850 & & 1 & 1 & Paunero, 2010 \\
\hline 45 & Fitz Roy & $\mathrm{n} / \mathrm{d}$ & 2 & & 2 & Carlini, pers. com. \\
\hline 46 & Puerto Deseado & $\mathrm{n} / \mathrm{d}$ & 1 & & 1 & Carlini, pers. com. \\
\hline 47 & Bahía Sanguineto (Lujanian stock) & $\mathrm{n} / \mathrm{d}$ & $\mathrm{x}$ & $\mathrm{x}$ & $\mathrm{x}$ & Ameghino, 1880 \\
\hline
\end{tabular}

Table 2

Frequencies of extinct and living mammals at archaeological sites in Pampa region.

\begin{tabular}{|c|c|c|c|c|c|c|}
\hline \# & Pampa sites in Fig. 1 & ${ }^{14} \mathrm{C}$ dating & Extinct & Living & N species & References \\
\hline 48 & Arroyo Seco 2. Fauna & $12,240 \pm 110-11,190 \pm 110$ & 12 & 15 & 27 & Politis et al., 2014 \\
\hline 49 & Arroyo Seco 2. Human occupation & $11,320 \pm 110-11,000 \pm 100$ & 10 & 13 & 23 & Politis et al., 2014 \\
\hline 50 & Paso Otero 5 & $10,440 \pm 100-10,210 \pm 50$ & 10 & 2 & 12 & Martínez and Gutiérrez, 2011 \\
\hline 51 & Cerro La China & $10,804 \pm 75-10,525 \pm 74$ & 1 & 0 & 1 & Mazzia, 2011 \\
\hline 52 & Tixi cave & $10,375 \pm 90-10,045 \pm 95$ & 2 & 13 & 15 & Mazzanti and Quintana 2001 \\
\hline 53 & Los Pinos & $10,465 \pm 65-8750 \pm 160$ & 2 & 13 & 15 & Mazzanti et al., 2013 \\
\hline 54 & Amalia site 2 & $10,425 \pm 75$ & 2 & 13 & 15 & Martínez and Osterrieth, 2003 \\
\hline 55 & Cueva Burucuyá & $10,000 \pm 120$ & 1 & 14 & 15 & Mazzanti et al., 2013 \\
\hline 56 & Paso Otero 4 & $9283 \pm 83-7314 \pm 73$ & 2 & 16 & 19 & Álvarez et al., 2013 \\
\hline 57 & Campo Laborde & $8090 \pm 190-7750 \pm 250$ & 3 & 6 & 9 & Politis and Messineo, 2008 \\
\hline 58 & Lobería 1 sitio 1 & $9878 \pm 81$ & 2 & 28 & 30 & Mazzanti et al., 2013 \\
\hline 59 & Los Helechos & $9640 \pm 40$ & 0 & 8 & 8 & Mazzia, 2011 \\
\hline 60 & El Abra cave & $9834 \pm 65$ & 1 & 14 & 15 & Quintana et al., 2003 \\
\hline 61 & La Brava cave & $9670 \pm 120$ & 0 & 9 & 9 & Mazzanti, 1999 \\
\hline 62 & El Guanaco 1 & $9250 \pm 40-7494 \pm 74$ & 3 & 6 & 9 & Frontini, 2012 \\
\hline 63 & Arroyo Seco 2. Human burials & $8980 \pm 410-7043 \pm 82$ & 5 & 18 & 23 & Politis et al., 2014 \\
\hline 64 & La Moderna & $8356 \pm 65-7448 \pm 109$ & 3 & 6 & 9 & Politis and Gutiérrez 1998 \\
\hline 65 & El Guanaco 2 & $9140 \pm 120-8123 \pm 82$ & 1 & 2 & 3 & Frontini, 2012 \\
\hline 66 & Laguna de Los Pampas without human & $8971 \pm 77-8835 \pm 83$ & 3 & 7 & 10 & Politis et al., 2012 \\
\hline
\end{tabular}


(hairy and cingulates), and notoungulates emigrated to the North, (Cione et al., 2009).

Of the 12 Holarctic families (excluding Hominidae) which emigrated to South America from the limit Pliocene-Pleistocene, felids, ursids, camelids and equids (Equus and Hippidion), along with the South American native fauna, made up the Lujanian fauna that at the end of the Pleistocene was found by hunter-gatherer pioneers in Pampa and Patagonia. Of the 122 Lujanian species, only 16 have archeological record between both regions. On the other hand, if we only register those corresponding to mega mammals and large mammals, the use could have been much lower as regards selected species (Fig. 2).

Even though the biodiversity was greater during the period of late Pleistocene and early Holocene, when the first signals of human settlement in the south of South America were recorded (ca.13 $\mathrm{Ka}$ BP), it was lower in Patagonia than that recorded in Pampa region (Miotti and Salemme, 1999).

Of the 14 extinct species of large mammals, 12 are Holarctic type and two are native from South America, of these, those corresponding to mega fauna were fully extinct (Alberdi et al., 1995; Cione et al., 2009, pp. 135). The biotic interchange did not produce an irreversible declination of biodiversity, which even increased in South America towards the end of Pleistocene, especially at the expense of the immigrants. Some mega mammals (glyptodonts) managed to survive the dramatic postglacial changes, until ca. of 7.5 $\mathrm{Ka}$ BP, date of the last appearance in Pampa region (Politis and Gutiérrez, 1998; Miotti and Salemme, 1999; Politis et al., 2004; Cione et al., 2015).

In this context, it is worth highlighting that if humans only hunted some of the mega and large mammal species of the Lujanian stock, this action did not cause the extinction firsthand, but rather a kind of chain reaction in the highly unstable ecosystems of the end of Pleistocene, which were producing a numerical reduction of these animal populations. In that sense, the numerical decline of large and mega mammals that had already been subjected to re-accommodation due to profound postglacial environmental changes was accelerated by human presence since the selective hunting managed to break the weakened food chains, and this way favored the eventual extinction of different species. In this respect, it cannot be established a sequence of extinctions between mega, large and small mammals due to the focus of human interest for certain preys. These hunts, when reducing selectively some populations of mega and large mammals, managed to break the ecological balance between faunas and their environments, being therefore an extremely disturbing factor in the latter. An example of

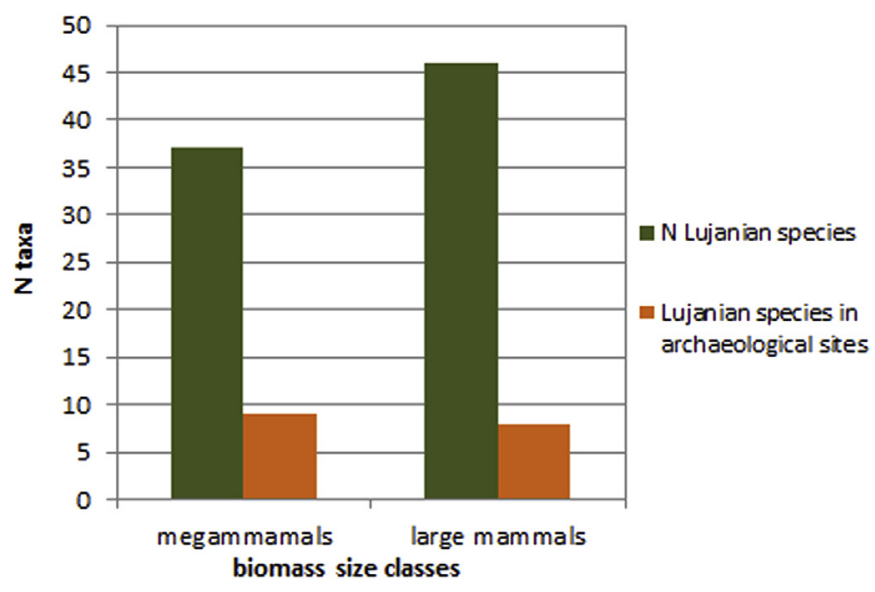

Fig. 2. Biodiversity estimated in Lujanian taxa. this is the case of guanacos that were, both in Pampa and in Patagonia, the species mostly used by hunter-gatherers, and they have reached the present time, in spite of the fact that hunting was sustained by humans in both regions throughout all Holocene.

\section{Zooarchaeological database}

All archeological sites with accurate chronological and taxonomic information about the presence of Lujanian fauna species were considered for this work. Moreover, the paleontological information whose temporal dispersion coincides, at least in part, with the human presence in both regions was also taken into account. In some cases, they are penne contemporary and in others, the taxa date is available specifying even more the presence of determined taxa in an area. Thus, we analyzed 18 sets for Pampa region and 44 sets for Patagonia, having both present and extinct fauna and with taxa of large and mega mammals. Also, those taxa of medium mammals were taken into account, but only the presence/ absence of those of small and micro mammals was reported since their information is very heterogeneous in the publications. Tables 1a and 1b, 2 and 3 show these data summarized and the other taxa recorded in Pampa and Patagonia sites. These data are considered indispensable for the analysis of biodiversity and fauna use in different environments of both regions.

\section{Zooarchaeological results}

The results of the relative taxonomic abundance expressed in Ntaxa obtained for both regions have resulted from the quantitative analyses of each site (Tables 1-4; Figs. 3 and 4).

In all sites of both regions, the common factor is the Lama guanicoe species, which, as it was seen above, it is characterized by the high environmental adaptability, even in very eremic conditions. On the other hand, it is the species that even today inhabits in some sectors of the south and west portion of Pampa region and all Patagonian region, and exceeding its geographic dispersion, reaches the Andean territories of Argentina, Chile and Peru, and the Bolivian plateau. The zooarcheological remains indicate a high level of human consumption in both regions, moreover, its gregarious ethology and the preference for open steppe environments, together with the associated weapons in the archeological sites, allow inferring that these camelids were the favourite preys of the first hunter-gatherers, even until the post-Hispanic times (Borrero, 1990; Miotti, 1998; Mengoni Goñalons, 1999; Miotti and Salemme, 1999, 2004; Politis and Madrid, 2001; Miotti, 2012; Salemme and Miotti, 2008; among others).

We found out that in the time period previous to 12.6 Ka BP only archeological sites with Pleistocene fauna were recorded in Patagonia (Tables $1 \mathrm{a}, 1 \mathrm{~b}$, and 2 ), and only after that date, these taxa appeared represented in archeological sites of both regions, what indicates an older record of human-Pleistocene fauna co-existence for the Patagonian region. The only exception in Pampa corresponds to the archaeological site Arroyo Seco 2, which seems to

Table 3

Temporal and regional faunal distributions.

\begin{tabular}{|c|c|c|c|c|c|c|}
\hline \multirow{2}{*}{$\begin{array}{l}\text { Regions } \\
\mathrm{N} \text { taxa } \\
\text { Intervals }\end{array}$} & \multicolumn{3}{|c|}{ Patagonia } & \multicolumn{3}{|l|}{ Pampa } \\
\hline & Extinct & Living & $\mathrm{N}$ sites & Extict & Living & $\mathrm{N}$ sites \\
\hline $13.5-12.5 \mathrm{Ka} \mathrm{ВР}$ & 8 & 5 & 8 & 0 & 0 & 0 \\
\hline $12.5-11$ Ка ВР & 8 & 4 & 11 & 17 & 12 & 2 \\
\hline $11-9.5$ Ка ВР & 5 & 18 & 15 & 6 & 28 & 12 \\
\hline $9.5-7.5 \mathrm{Ka} \mathrm{BP}$ & 2 & 12 & 10 & 4 & 23 & 5 \\
\hline Total N sites & 22 & 38 & 44 & 27 & 63 & 19 \\
\hline
\end{tabular}


Table 4

Species with archaeological record.

\begin{tabular}{|c|l|c|c|}
\hline Code & Taxa & Patagonia & Pampa \\
\hline 1 & Gastropods & $\mathrm{x}$ & $\mathrm{x}$ \\
\hline 2 & Volutidae (marine snail ) & $\mathrm{x}$ & $\mathrm{x}$ \\
\hline 3 & Aulacomya ater & $\mathrm{x}$ & \\
\hline 4 & Amiantis sp. & $\mathrm{x}$ & $\mathrm{x}$ \\
\hline 5 & Adelomelon brasiliensis & $\mathrm{x}$ & $\mathrm{x}$ \\
\hline 6 & Fishes & & $\mathrm{x}$ \\
\hline 7 & Anura and ophidia & $\mathrm{x}$ & $\mathrm{x}$ \\
\hline 8 & Ave & $\mathrm{x}$ & \\
\hline 9 & Polyborus sp & $\mathrm{x}$ & $\mathrm{x}$ \\
\hline 10 & Phonicopterus ruber & $\mathrm{x}$ & $\mathrm{x}$ \\
\hline 11 & Rheidae & $\mathrm{x}$ & \\
\hline 12 & Rhea americana & & $\mathrm{x}$ \\
\hline 13 & Pterocnemia pennata & & $\mathrm{x}$ \\
\hline 14 & Eudrommia eleqans & & $\mathrm{x}$ \\
\hline 15 & Nothura maculosa & \\
\hline 16 & Fulica sp. & & \\
\hline 17 & Speotyto cunicularia & & \\
\hline
\end{tabular}

Mammals

\begin{tabular}{|l|l|l|l|}
\hline $18 *$ & Scelidotherium & $\mathrm{x}$ & $\mathrm{x}$ \\
\hline
\end{tabular}

19 Mylodon darwini/ listait

20 Megatherium americanum

21 Lestodon armatus

22 Glossotherium sp. $\dagger$

23 Eutatus seguini†

24 Glyptodon sp. ${ }^{\dagger}$

25 Panocthus $\mathrm{sp} \dagger$

26 Doedieurus sp. $\dagger$

27 Sclerocalypthus

28 Tolypeutes

\begin{tabular}{l|l|l|}
29 & & $\mathrm{x}$ \\
\hline & Choetophractus villosus & $\mathrm{x}$ \\
\hline
\end{tabular}

31 Dasypus hybridus

32 Holochilus brasiliensis

33 Dolichottis patagonum

34 Lagostomus maximus

35 Myocastor coypus

36 Lagidium sp

37 Pantera oncat

38 Conepatus sp

39 Lutreolina cassicaudata

40 Felis $\mathrm{sp}$.

41 Smilodon $\mathrm{sp}+$

\begin{tabular}{|l|l|l|l|}
\hline 42 & Felis concolor & $\mathrm{x}$ & \\
\hline 43 & L & $\mathrm{x}$ & $\mathrm{x}$ \\
\hline
\end{tabular}

43 Lynchailorus colo-colo

44 Lontra sp.

45 Arctotherium tarijense

46 Canis $s p$

47 Canis (D.) avus †

48 Canis (D.) culpaeus

49 Lyncodon patagonicus

50 Macrauchenia patachonica

51 Palaeolama wedelli $;$

52 Toxodon sp.†

53 Cuveronius sp $\dagger$

54 Equus (amerhippus) neogaeus

55 Hippidion saldiasi +

56 Tayassu sp.

57 Lama $\mathrm{sp}$

58 Lama (V.) gracilis $\dagger$

59 Lama guanicoe

60 Hemiauchenia paradoxa ${ }^{+}$

61 Ozotoceros bezoarticus

62 Hippocamelus bisulcus

63 Pudu pudu

Homo sapiens

$\mathrm{N}$ taxa

\begin{tabular}{|c|c|}
\hline $\mathrm{x}$ & $\mathrm{x}$ \\
\hline \multirow[t]{6}{*}{$\mathrm{x}$} & $\mathrm{x}$ \\
\hline & $\mathrm{x}$ \\
\hline & $\mathrm{x}$ \\
\hline & $\mathrm{x}$ \\
\hline & $\mathrm{x}$ \\
\hline & $\mathrm{X}$ \\
\hline \multirow{5}{*}{$\mathrm{x}$} & \\
\hline & $\mathrm{x}$ \\
\hline & $\mathrm{x}$ \\
\hline & $\mathrm{x}$ \\
\hline & $\mathrm{x}$ \\
\hline \multirow[t]{6}{*}{$\mathrm{x}$} & $\mathrm{x}$ \\
\hline & $\mathrm{x}$ \\
\hline & $\mathrm{x}$ \\
\hline & $\mathrm{x}$ \\
\hline & $\mathrm{X}$ \\
\hline & $\mathrm{x}$ \\
\hline $\mathrm{x}$ & $\mathrm{x}$ \\
\hline $\mathrm{x}$ & \\
\hline \multirow[t]{2}{*}{$\mathrm{x}$} & \\
\hline & $\mathrm{x}$ \\
\hline $\mathrm{x}$ & $\mathrm{x}$ \\
\hline $\mathrm{x}$ & \\
\hline $\mathrm{x}$ & $\mathrm{x}$ \\
\hline $\mathrm{x}$ & \\
\hline $\mathrm{x}$ & \\
\hline $\mathrm{x}$ & \\
\hline $\mathrm{x}$ & $\mathrm{x}$ \\
\hline $\mathrm{x}$ & $\mathrm{x}$ \\
\hline $\mathrm{x}$ & $\mathrm{x}$ \\
\hline $\mathrm{x}$ & $\mathrm{x}$ \\
\hline $\mathrm{x}$ & $\mathrm{x}$ \\
\hline \multirow[t]{2}{*}{$\mathrm{x}$} & \\
\hline & $\mathrm{x}$ \\
\hline \multirow[t]{2}{*}{$\mathrm{x}$} & \\
\hline & $\mathrm{x}$ \\
\hline \multirow[t]{2}{*}{$\mathrm{x}$} & $\mathrm{x}$ \\
\hline & $\mathrm{x}$ \\
\hline $\mathrm{x}$ & $\mathrm{x}$ \\
\hline $\mathrm{x}$ & $\mathrm{x}$ \\
\hline $\mathrm{x}$ & $\mathrm{x}$ \\
\hline \multirow[t]{2}{*}{$\mathrm{x}$} & $\mathrm{x}$ \\
\hline & $\mathrm{x}$ \\
\hline $\mathrm{x}$ & \\
\hline $\mathrm{x}$ & \\
\hline $\mathrm{x}$ & $\mathrm{x}$ \\
\hline 38 & 48 \\
\hline
\end{tabular}

† extinct species $\square$ megamammal $\square$ large mammal $\square$ medium and small size fauna

$\mathrm{N}^{\circ} 18^{*}$, Scelidotherium includes remains of one young individual assigned to Diabolotherium cf. nordenskioldi, Which and is related to Scelidotherium. 

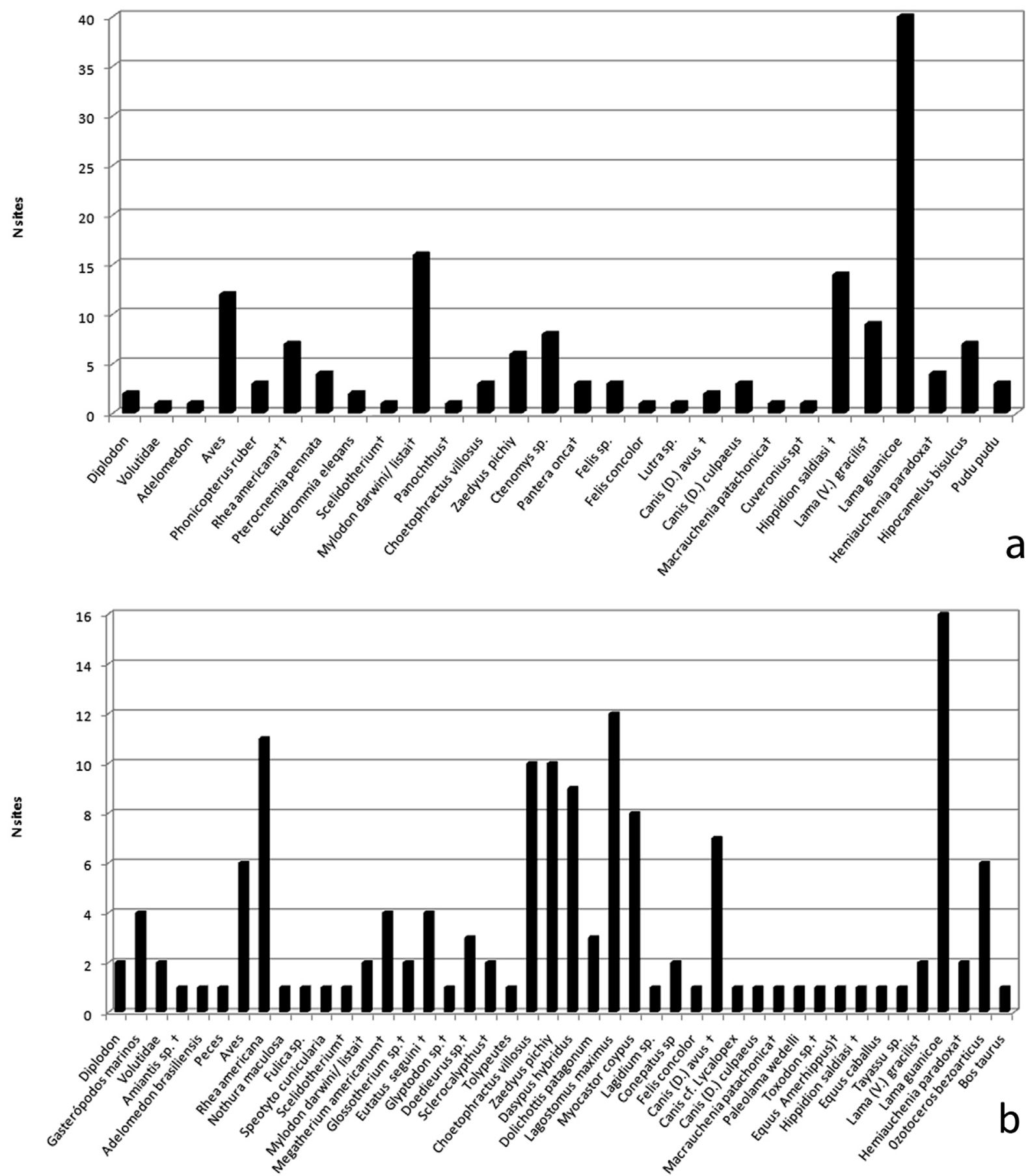

Fig. 3. Taxonomic frequency in a) Patagonia, and b) Pampa. $\dagger$ extinct species. $\dagger \dagger$ dessapear in the region.

meet this condition of presenting a high number of mega and large mammal species for 12,600-12,000 RYBP. Nevertheless, the detailed information obtained from the taphonomic analyses indicate that for the inferior levels of the site, humans only hunted/ used few of all the taxa present in the area (Politis, 2014). On the other hand, even though the spatial distribution of faunas with Lujanian elements is greater in Patagonia than in Pampa, the latter presents a greater taxonomic diversity (Tables $1 \mathrm{a}-\mathrm{b}, 2$ and 3 and Figs. 2 and 5).

\section{Characteristics of the species with archaeological record}

The species that we consider as key in this work correspond to the association of Lujanian mammals corresponding to the Biozone of Equus (A) neogaeus Association, according to Cione et al. (2009), since these are the ones that had better chances of having coexisted a longer time with the first humans, and therefore, having being exploited by the hunter-gatherers that colonized both regions of South America (Fig. 5). 

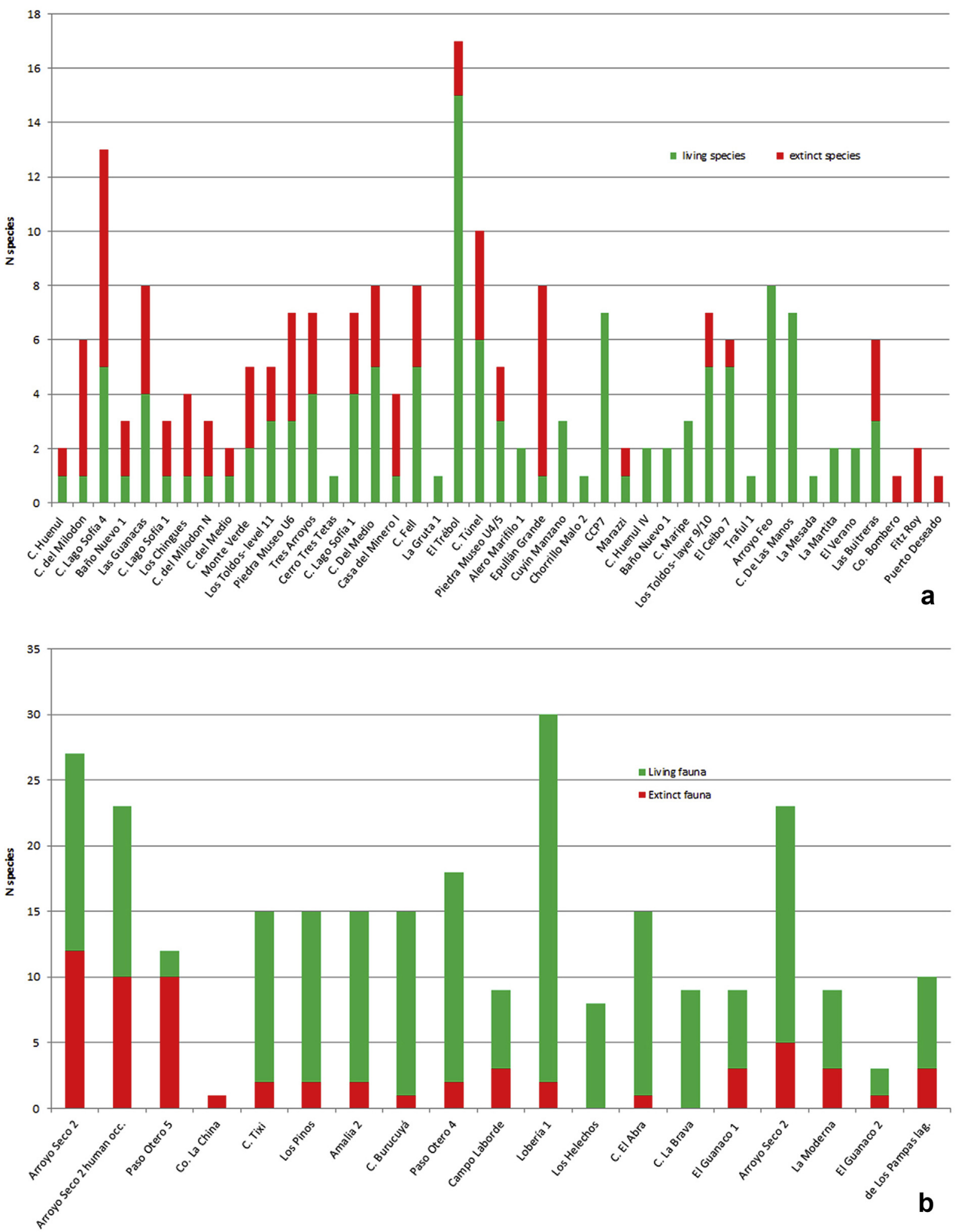

Fig. 4. Taxonomic abundance (living and extinct mammals) in a) Patagonia and b) Pampa sites.

Regarding the Xenarthra group, several findings can be mentioned in Southern Patagonia, though not always its association with archaeological sites is related with mylodonts. However, in 2007, in Fitz Roy locality (\#45), Santa Cruz province, during the excavations for a sport building, remains of (Panochthus), and others referred to Scelidotherium (A. Carlini, com. pers.) were found. Both taxa form part of the Lujanian fauna (late Pleistocene) and, so far, they have not been documented in sites of the Patagonian region, since only accuracy ascribed those of Bahia Sanguineto (\#47) and Puerto Deseado (\#46) to Lujanian xenarthrans remains (Tonni 


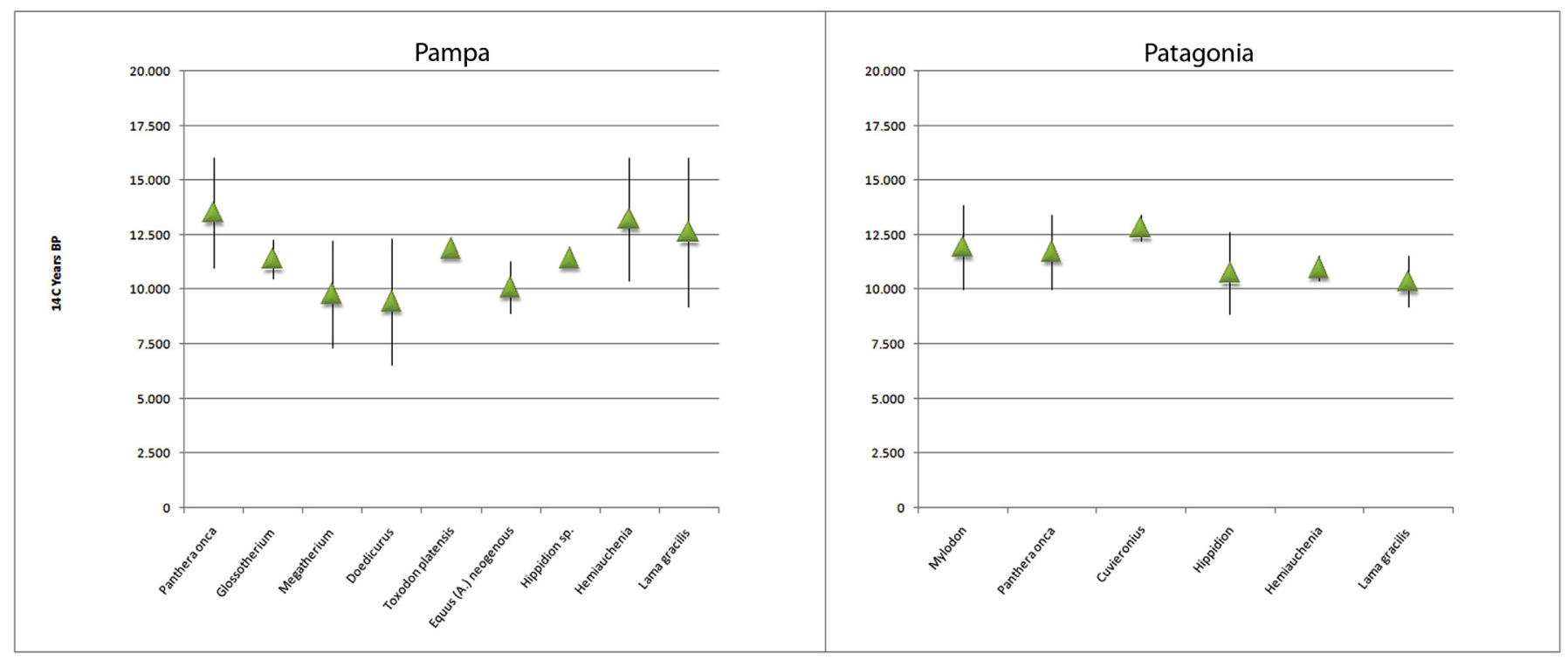

Fig. 5. Date of first and last appearance of species of Lujanian fauna in both regions. a) Patagonia y b) Pampa.

and Carlini, 2008). Such mammals appear stratigraphically in sediments of lagoon and swamp type, as well as wind type, and their habitats were those of open savanna and grasslands related to periglacial areas and with temperatures lower than today. In both regions these basic ecological characteristics for Lujanian mammals were confirmed by independent evidence lines such as palynology, the studies of sea cores, and stable isotopes (Czerwonogora et al., 2011).

\section{Dates of the first and last appearance of extinct taxa}

The results of taxa dates obtained in archaeological sites of Pampa and Patagonia allow supporting the hypothesis that Pleistocene large and mega mammals had a period of coexistence with humans of $c a$. 5000 years (Cione et al., 2009). However, the coexistence times between humans and mega fauna were different in the different species, in both regions. In Fig. 5 it is shown this situation based on the zooarchaeological information of each region.

This analysis together with the zooarchaeological information of the previous paragraph allows suggesting that hairy Xenarthra (sloths) and Cingulates (glyptodonts) had greater possibilities of becoming prey for humans in Pampa region. This difference is based on the fact that, in Pampa region, the Cingulates disappeared by mid-Holocene,ca. 7.5 Ka BP (Politis and Gutiérrez, 1998; Gutiérrez et al., 2010), while in Patagonia the last records correspond to the end of the transition Pleistocene/Holocene, i.e., $\mathrm{ca} .10$ Ka BP (Borrero and Martin, 2012; Marchionni and Vázquez, 2012; Miotti and Marchionni, 2012; Martin, 2013) (Fig. 5). This may suggest that the potentiality of these animals as resource for human consumption was extended 2500 years more in Pampa than in Patagonia. On the other hand, their most abundant use in the former region is supported by the vast evidence of primary butchering and consumption marks, and the greatest taxonomic richness per taxon (Table 4 and Fig. 3).

In Patagonia there are no records of glyptodont remains in archaeological sites (Table 4 and Fig. 3) but there have been numerous findings of giant sloths; though in very few of these findings there is clear evidence of butchering marks and anthropic burnt (Borrero et al., 1997; Miotti and Cattáneo, 2003; Hajduk et al., 2009, 2012; Lezcano et al., 2010; Marchionni and Vázquez, 2012; Marchionni, 2013; Miotti and Marchionni, 2012, 2014). However, in this region the number of archaeofauna elements is overdimensioned since the most represented parts in almost all the Patagonian sites correspond to dermal bones and in some cases, like in the Milodón Cave and Baño Nuevo-1 cave (Fig. 1), to leather fragments with little bones included. This evidence of several dermal bones is a key marker for being able to interpret these findings in function of the human choice regarding the use of sloths. This recurrent data in different Patagonian caves encouraged the hypothesis of an initial cave occupation by animals, and then, a subsequent use by humans. In this case, there may be a temporal difference between the megafauna occupation and humans. The taphonomic and stratigraphic studies indicate natural death of animals and previous to peoples at caves (Mena and Reyes, 2001; Borrero and Martin, 2012). In others caves, like Huenul 1, Milodón, Los Chingues, the first stratigraphic levels contain milodont's dungs. However, in some cases like in El Trebol cave (Fig. 1 \#21) signals of use of mylodonts are clearer. The excavators inferring that mylodonts were used by humans: "Algunos huesos dérmicos presentan una pátina negro brillante, indicando que fueron expuestos al fuego cuando aún conservaban restos de tejido blando." (Hajduk et al., 2009, pp. 959, pp. 959) ... "El rasgo más destacable en estos huesos dérmicos (Mylodontinae) es la presencia de claras huellas de corte producidas por el hombre, en algunos casos profundas y reiteradas." (Hajduk et al., 2009, pp. 960). The hypothesis of the use of dead animal leather and meat should not be discarded by the arguments further discussed.

The presence of notoungulates is very scarce in the analyzed archaeological sites, being absent in the Patagonian record, while, in Pampa region their presence is exclusively in Arroyo Seco 2 site only, with the species Toxodon platensis (Politis et al., 2014; Salemme, 2014). It is observed that this evidence may only support the hypothesis of coexistence between humans and such species since the record corresponds to a single carpal, which is dated $11,750 \pm 70$ (CAMS16839) ${ }^{14} \mathrm{C} \mathrm{BP}$ and does not present evidence of human action. However, this information together with the taxon dates of the site (Politis, 2014) indicate low chances that the species had coexisted during a long time with the first settlers of the area, therefore it seems parsimonious to keep the hypothesis of coexistence with the humans for a short time, but we do not believe that this species could have form part of the group of resources chosen by humans for consumption. This reasoning may explain partly the 
low archaeological representation of the species at Pampean regional level, since this is indeed frequent in paleontological groups of the end of Pleistocene.

Horses have a higher numerical representation in Patagonian contexts than in Pampa ones (Fig. 3), being their last appearance date 2000 years earlier in Pampa than in Patagonia (Fig. 5). Their longer coexistence period with humans in Patagonia could have been an important cause for having been more intensely used in this region. However, there are other archaeological markers that allow inferring a more intense use of equids by hunter-gatherers in Patagonia. Among these markers, there are equid images recorded in rock art from Los Toldos, La Maria and Piedra Museo sites (Cardich, 1987; Miotti, 1991, 1993-96; Miotti et al., 2007; Miotti and Carden, 2007; Paunero et al., 2007; Carden, 2009), most of the anatomic units, of different age categories, and abundant and clear cut/blow marks of butchering for the species Hippidion saldiasi in several Patagonian sites support the hypothesis about economic use of these mammals.

On the other hand, it is worth highlighting that in Patagonia there is only one species recorded, Hippidion saldiasi, while in Pampa the equids were represented by two species, Hippidion sp. (probably H. principale) and Equus (Amerhippus) neogaeus, though these are recorded in an only archaeological site, Arroyo Seco 2 (AS2). Even though in recent works, the archaeologists consider that in Pampa region both species were available, only Equus is the species with evidence of human use (Gutiérrez and Johnson, 2014; Salemme, 2014). These marks of cut and fracture impact are still scarce and they were recorded in a bone (radius) of those recovered in the only archaeological site where the species appeared represented (Gutiérrez and Johnson, 2014, pp. 124; Salemme, 2014, Table 4.8).

In Patagonia Hippidion saldiasi was recorded in fourteen localities: Los Toldos 2 and 3, Piedra Museo AEP-1, La María, Túnel cave, Casa del Minero 1, Cave 6 from El Ceibo, Lago Sofía 1 and 4; Fell, Pali Aike, Cueva del Medio, Los Chingues cave, Del Puma cave, and Tres Arroyos rockshelter, being the representation of anatomic units numerous in each site, generally corresponding to individuals of different age groups and presenting clear marks of prey processing. In this region, the time of the last equid appearance reached the early Holocene, around 8.5 Ka BP, recorded with taxon date in cerro Bombero site (Paunero, 2010). This evidence, combined with the gregarious nature of these mammals, an ethology similar to that of camelids, which undoubtedly were the most important preys in both regions, allows stating that the coexistence with equids may have been another factor contributing to adjust this species with the programmed hunting strategies of the first inhabitants in the Patagonian region. In such sense, horses are considered a selected resource searched by the first settlers of the southern extreme, and in Patagonia, they might have been very interesting in the economic, social and symbolic spheres. Probably, we should expect new evidence for supporting that a similar use of equids took place among hunter-gatherers in Pampa region.

In both regions, the species with more possibilities of having been important prey for humans is the camelids (Figs. 3 and 4), and within them the guanacos, which are considered main resources for hunter-gatherers until late Holocene. The abundance of remains of these mammals in most sites of both regions, along with the fact that their presence continues nowadays, supports such hypothesis. This record that leads to a strategy of hunting specialization during mid Holocene (Miotti and Salemme, 1999; Miotti, 2012, and references therein) is now outlined as a trend in hunting strategies which may have started at the beginning of human occupation.

As regards other extinct camelids, present in the first settlings in both regions, they also have a different representation. While Hemiauchenia paradoxa and Lama gracilis have an ephemeral evidence in Pampa region, with presence only in site AS 2, their record in Patagonia is much higher in number of sites and in amount of anatomic parts, as well as in amount of cut and chop traces (Nami and Menegaz, 1991; Miotti, 1998; Miotti and Salemme, 2005; Miotti and Marchionni, 2012; Martin, 2013). In this case, it can also be interpreted that the longest date of the last appearance in Patagonian sites (ca. 9.2 ka BP), together with an ethology similar to that of guanacos, may have contributed to the greatest and longest consumption of these mammals in the most southern region.

The large carnivores, such as the Panthera onça, have a very low archaeological representation in sites of Patagonia (Fig. 5) and null in those of Pampa. However, this species that nowadays lives in rain forests as far as the North of Argentina, inhabited both regions towards the end of Pleistocene. In Patagonia, the time of coexistence with humans was of 2000 years (Fig. 5), being ca. 10 ka BP the last records of the subspecies Panthera onça mesembrina. In Pampa Panthera onça inhabited until the beginning of the 20th century, but there are no archaeological records of the use given to this species by the first settlers in this region. This unequal archaeological evidence in both regions brings into questions the different use of these large felines by humans (Table 6). Taking into account that in Pampa the time of coexistence was much longer, the most parsimonious hypothesis is that the Pampean hunter-gatherers had not used jaguars as economic, social or symbolic resource (Table 6). On the contrary, and although a short period of coexistence was recorded in Patagonia, the archaeological evidence indicates that these animals formed part of, at least, the social and symbolic spheres of the first humans (Table 6). The sites where teeth of this species were recorded are Cueva del Medio, La María and El Ceibo. In this last Locality it was also documented a very big painting, assigned to that feline (Cardich, 1987; Miotti and Carden, 2007). This form of appropriation of one of the extinct species corresponding to a large carnivore, which at the same time was predator of Pleistocene large and mega mammals, is, in every sense, assignable to the symbolic category. This interpretation considers that the evidence of their remains associated to the first archaeological contexts is related with large images, outstanding on painting panels as well as with the appropriation of tusks and paws. This information supports the hypothesis of image appropriation or of parts of these large carnivores as elements that even today are considered mimetic of super natural power in several societies (González, 1974; Reichel-Dolmatoff, 1975; Dillehay and Kaulick, 1984-85; Ingold, 1986; Taçon et al., 1996; Politis and Saunders, 2002; Miotti and Carden, 2007), and in that sense, that those items might have been considered as metonymic and/or metaphoric of prestige and/or power among the first Patagonian explorers. However, such evidence is not enough for formulating the incidence in hunting for an economic use. In numerous societies, from hunter-gatherers to agricultural or pastoral, the jaguar image as power symbol and social belonging has been important until today, in ceremonies, artifacts, artistic representations, legends and other narratives as well (see references above).

\section{Discussion}

The zooarchaeological, ethological, coeval information between humans and Pleistocenic extinct fauna presented here supports the hypothesis of Broken Zig Zag (see, Cione et al., 2009, 2015, and citations therein) as a varied and complex set of environmental and cultural factors of mammal extinction. In this frame, the amount of taxa of extinct fauna appearing in archaeological sites of first colonization in both regions does not exceed the $30 \%$ of the total (Fig. 2), therefore they are few as regards those of living species in Holocene which were used, firstly, as product of human hunting. As 
Table 5

Ecological and ethological characteristics of extinct Pleistocene mammals with archaeological record.

\begin{tabular}{|c|c|c|c|c|c|c|}
\hline Lujanian Species & behavior & Activity & feeding habits & $\begin{array}{l}\text { Potential } \\
\text { depredators }\end{array}$ & environment & climate \\
\hline Panthera onça & lonely & $\begin{array}{l}\text { crepuscular/ } \\
\text { dusk }\end{array}$ & carnivore & unknown & $\begin{array}{l}\text { Forest/moist } \\
\text { Savanna }\end{array}$ & $\begin{array}{l}\text { tropical/ } \\
\text { temperate }\end{array}$ \\
\hline Smilodon Sp & lonely & diurnal & carnivore & without & Savanna & cool temperate \\
\hline Arctotherium tarijense & lonely & $\begin{array}{l}\text { diurnal/ } \\
\text { daytime? }\end{array}$ & omnivore & without & $?$ & cool temperate \\
\hline Canis (D) avus & lonely & $\begin{array}{l}\text { diurnal/ } \\
\text { dusk }\end{array}$ & omnivore & unknown & Savanna/steppe? & cool temperate \\
\hline Scelidotherium Sp & $?$ & $\begin{array}{l}\text { diurnal/ } \\
\text { daytime }\end{array}$ & $?$ & $\begin{array}{l}\text { grand carnivores/ } \\
\text { human }\end{array}$ & Savanna/grassland & cool temperate \\
\hline Lestodon armatus & $?$ & $\begin{array}{l}\text { diurnal/ } \\
\text { daytime }\end{array}$ & $?$ & $\begin{array}{l}\text { grand carnivores/ } \\
\text { human }\end{array}$ & Savanna/grassland & cool temperate \\
\hline Mylodon darwini/listai & $?$ & $\begin{array}{l}\text { diurnal/ } \\
\text { daytime }\end{array}$ & grazer & $\begin{array}{l}\text { grand carnivores/ } \\
\text { human }\end{array}$ & open shrub steppe & cool temperate \\
\hline Megatherium Sp & lonely? & $\begin{array}{l}\text { diurnal/ } \\
\text { daytime }\end{array}$ & grazer & $\begin{array}{l}\text { grand carnivores/ } \\
\text { human }\end{array}$ & Savanna/grassland & cool temperate \\
\hline Glossotherium Sp. & lonely? & $\begin{array}{l}\text { diurnal/ } \\
\text { daytime }\end{array}$ & grazer & $\begin{array}{l}\text { grand carnivores/ } \\
\text { human }\end{array}$ & Savanna/grassland & cool temperate \\
\hline Eutatus seguini & lonely? & $\begin{array}{l}\text { diurnal/ } \\
\text { daytime }\end{array}$ & grazer & $\begin{array}{l}\text { grand carnivores/ } \\
\text { human }\end{array}$ & Savanna/grassland & cool temperate \\
\hline Gliptodon Sp & lonely? & $\begin{array}{l}\text { diurnal/ } \\
\text { daytime }\end{array}$ & grazer & $\begin{array}{l}\text { grand carnivores/ } \\
\text { human }\end{array}$ & Savanna/grassland & cool temperate \\
\hline Panochthus Sp & lonely? & $\begin{array}{l}\text { diurnal/ } \\
\text { daytime }\end{array}$ & grazer & $\begin{array}{l}\text { grand carnivores/ } \\
\text { human }\end{array}$ & Savanna/grassland & cool temperate \\
\hline Doedicurus Sp & lonely? & $\begin{array}{l}\text { diurnal/ } \\
\text { daytime }\end{array}$ & grazer & $\begin{array}{l}\text { grand carnivores/ } \\
\text { human }\end{array}$ & Savanna/grassland & cool temperate \\
\hline Sclerocalypthus Sp & lonely? & $\begin{array}{l}\text { diurnal/ } \\
\text { daytime }\end{array}$ & grazer & $\begin{array}{l}\text { grand carnivores/ } \\
\text { human }\end{array}$ & Grassland/schrubby & cool temperate \\
\hline Toxodon Sp & herd? & $\begin{array}{l}\text { diurnal/ } \\
\text { daytime }\end{array}$ & grazer & $\begin{array}{l}\text { grand carnivores/ } \\
\text { human }\end{array}$ & wetland? & cool temperate \\
\hline Macrauchenia Sp & herd? & $\begin{array}{l}\text { diurnal/ } \\
\text { daytime }\end{array}$ & grazer & $\begin{array}{l}\text { grand carnivores/ } \\
\text { human }\end{array}$ & Grassland/schubby & cool temperate \\
\hline Gomphoteriidae & herd & $\begin{array}{l}\text { diurnal/ } \\
\text { daytime }\end{array}$ & grazer & $\begin{array}{l}\text { grand carnivores/ } \\
\text { human }\end{array}$ & Grassland/woodland & cool temperate \\
\hline Hippidion saldiasi & herd & $\begin{array}{l}\text { diurnal/ } \\
\text { daytime }\end{array}$ & grazer & grand carnivores/human & Plains and mountain & cool and wet \\
\hline Equus (A.) neogaeus & herd & $\begin{array}{l}\text { diurnal/ } \\
\text { daytime }\end{array}$ & grazer & $\begin{array}{l}\text { grand carnivores/ } \\
\text { human }\end{array}$ & Plains and mountain & cool temperate \\
\hline Hemiauchenia paradoxa & herd? & $\begin{array}{l}\text { diurnal/ } \\
\text { daytime }\end{array}$ & grazer & $\begin{array}{l}\text { grand carnivores/ } \\
\text { human }\end{array}$ & Grassland/schrubby & cool temperate \\
\hline Lama gracilis & herd & $\begin{array}{l}\text { diurnal/ } \\
\text { daytime }\end{array}$ & grazer & $\begin{array}{l}\text { grand carnivores/ } \\
\text { human }\end{array}$ & grassland, schubby & cool temperate \\
\hline Lama guanicoe & herd & $\begin{array}{l}\text { diurnal/ } \\
\text { daytime }\end{array}$ & grazer & $\begin{array}{l}\text { grand carnivores/ } \\
\text { human }\end{array}$ & Grassland/schubby steppe & cool temperate \\
\hline Ozotoceros bezoarticus & herd & $\begin{array}{l}\text { diurnal/ } \\
\text { daytime }\end{array}$ & grazer & $\begin{array}{l}\text { grand carnivores/ } \\
\text { human }\end{array}$ & Grassland plains & $\begin{array}{l}\text { tropical/ } \\
\text { temperate }\end{array}$ \\
\hline
\end{tabular}

Table 6

Different human uses of mammalian fauna in Pampa and Patagonia regions.

\begin{tabular}{|c|c|c|c|c|c|c|}
\hline \multirow{2}{*}{$\begin{array}{l}\frac{\text { Regions }}{\text { Use of Taxa }} \\
\text { Taxa }\end{array}$} & \multicolumn{3}{|l|}{ Pampa } & \multicolumn{3}{|l|}{ Patagonia } \\
\hline & Economic & Social & Symbolic & Economic & Social & Symbolic \\
\hline Xenarthrans & yes & yes & yes & yes & yes & yes \\
\hline Equids & yes & $\mathrm{n} / \mathrm{d}$ & $\mathrm{n} / \mathrm{d}$ & yes & yes & yes \\
\hline Camelids & yes & yes & $\mathrm{n} / \mathrm{d}$ & yes & yes & yes \\
\hline $\begin{array}{l}\text { Grand } \\
\text { Carnivors }\end{array}$ & No Data & & & No & yes & yes \\
\hline
\end{tabular}

a consequence, even though it is observed that the glyptodonts lasted until mid Holocene for Pampa region (ca. 7 ka BP), in Patagonia, their disappearance was completed 3000 years before. However, we can suggest that in Patagonia the social and symbolic use of some extinct species may have indeed survived among hunter-gatherers until the end of Mid Holocene.

Thus, it is inferred that from the end of the Pleistocene to mid Holocene, biodiversity trends, both in Pampa in Patagonia, were decreasing with some variables in both regions (Fig. 6). The greatest

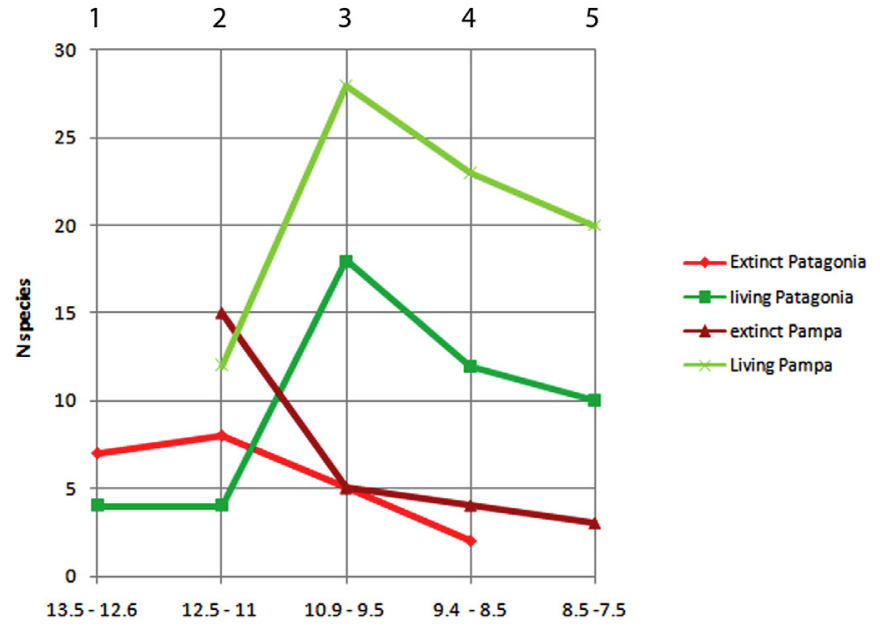

Fig. 6. Faunal diversity in Pampa and Patagonia: temporal trends. 1 to 5 are temporal intervals expressed in ka BP. 
mammal biodiversity recorded archaeologically at the end of Pleistocene or beginning of Holocene was due to the presence of mega and large mammals of Lujanian stock, which decreases in sites of both regions towards the second interval of human occupation, ca. 11.5 Ka BP (Fig. 6) because of the extinction process both of mega and large mammals. From that date, the inversion in diversity trends took place in both regions, between the extinct and present species. The variety of extinct species decreased abruptly and the representation of large living mammals increased. Even though the mostly used species was the guanaco in both regions from the beginning of the first settlers, the complementary resources changed, being the cervids which complemented the economic resources in Pampa and north Patagonia, while in Patagonia the specificity about guanacos was more significant (Fig. 4).

In Pampa, the first records of the Pleistocene fauna use in archaeological sites were later than in Patagonia, which indicates that the interaction (humans-extinct fauna) began roughly 1000 years earlier in Patagonian sites than in Pampa sites. The use of Pleistocenic fauna continued increasing in both regions during the third interval (10.9-9.5 Ka BP) and fourth interval (9.4-8.5 Ka BP), reaching the fifth interval (8.4-7.5 Ka BP) only with present fauna in both regions and the survival of cingulated xenarthrans only in Pampa region until 7 Ka BP (Fig. 6). Xenarthra disappeared 1000 years before in Patagonia ca. 8.5 Ka. BP, when in that region the extinction of all Pleistocene species was completed. Nevertheless, in Pampa, survival of some glyptodonts in environmental shelters of that region reached $c a .7 \mathrm{Ka}$ BP.

Another peculiarity, in both regions after $8.5 \mathrm{Ka}$. BP, is the most diverse use of taxa of both large and small mammals in Pampa region, while in Patagonia the almost exclusive resource was represented in the species Lama guanicoe, which was joined, as a complement, by some cervids in the Andean sector and pinnipedes on the Atlantic coast. The reduction in biodiversity in archaeological sites may have resulted from the extinction process. An outstanding issue of the fauna variations of both regions is that in Patagonia the taxonomic diversity was always below that recorded in Pampa region (Fig. 6). Despite this difference of a greater mammal variety in Pampa region than in Patagonia, in both regions the guanaco dominated all archaeological contexts before and after the great extinction of Pleistocene species. This supports the hypothesis of a greater adaptation between hunters and preys, positioning the guanaco as the main resource from the beginning of colonization. On the other hand, even with a wider biodiversity in Pampa than in Patagonia, the use of fauna was of larger spectrum in the human occupations of both regions until the third interval (Fig. 6), though with main contributions obtained from guanacos.

As regards the change of strategies of fauna appropriation, we observe that towards $10 \mathrm{Ka}$ BP the greatest biodiversity increment took place in both regions dominated by present faunas (Figs. 4-6). The contexts of hunting technology and zooarchaeological, until then, indicate that the prevailing strategy may have been the wide generalized hunting, though with a prevalence of large mammals such as guanacos. In both regions, the gregarious animals, such as the camelids and equids in Patagonia, and the camelids, equids and cervids in Pampa, seem to have been predominantly sought by humans as economic resources. However, in all sites, the anatomic richness and the richness of use and consumption evidence was always focused on guanacos. After $8.5 \mathrm{Ka} \mathrm{BP}$, the strategy in both regions changed, turning to a greater speciation on guanaco hunting (Miotti and Salemme, 1999; Miotti, 2012). Therefore, the change in strategy that in previous works (Miotti and Salemme, 1999) we placed between early Holocene and Mid Holocene, with the new regional information we are able to place it around 9.5 Ka BP, at the end of the third interval (Fig. 6).

In this sense, the hypothesis, which assigns the first humans a catalyst role in the process of megafauna extinction in South America, is still the most parsimonious (Cione et al., 2009, 2015). Even though, since the earliest peopling humans had used species of extinct and living Pleistocenic mammals, the archaeological evidence presented herein for both regions indicates that humans were not the main responsible for the extinction by mass slaughter but rather another factor which destabilized the environments already in crisis about 3000 years before the human arrival in South America. The human settling in a new environment produces changes in the ecosystems from their interaction. The interaction in those finipleistocenic environments where deep climatic and environmental changes had been taking place (Mc Culloch et al., 2000; Rabassa, 2008) produced the final disarticulation of trophic chains with differential extinction structures in different mammal species, and such species did not manage to overcome population decreases which repeatedly occurred before the human arrival in the continent (Cione et al., 2015).

Particular cases for both regions are those of giant sloths, glyptodonts and large carnivores such as jaguars. In Patagonia these mammal groups lived with humans around 2500 years (Fig. 5), however, the archaeological evidence suggests an opportunist use of giant sloths and jaguars, while the glyptodonts were only recorded in paleontological sites (No 45, 46 and 47 of Tables 1 and 2, and Fig. 1), and consequently, the appropriation of all these animals might have influenced more significantly the social and symbolic spheres than those economic. That is, they were used for learning about the new places and their beings but they were not focus of hunting strategies for satisfying their basic needs (food).

In Pampa, both groups lived longer with humans (Fig. 3), however, the same as in Patagonia, giant sloths acquired an opportunist appropriation, while it is impossible by now to assign any kind of human use of jaguars. This importance was reverted in this Pampean region in the case of glyptodonts (xenarthrans cingulates), from which there is clear evidence of economic (Álvarez et al., 2013; Politis et al., 2014; Salemme, 2014; Martínez et al., 2016), but is weakness of social and symbolic use (Table 6).

The discussion about anthropological, archaeological and palaeoecologial information allowed us to state that the knowledge about them lasted in the social imaginary, even after their extinction, through rock art, in curated and/or claimed artifacts, such as scutes, paws and teeth, present in some Pampean and Patagonian contexts. This materiality of the extinguished fauna may also be indicating that these animals had their social importance in the narratives of stories of places and people, possibly in ceremonies, myths and legends.

For horses (Equus [A.] and Hippidion) and camelids (Lama guanicoe and Lama gracilis), all of them herd mammals of grazing and running habits (Table 5), the archaeological and ethnographic evidence indicates a human appropriation through ambush and planned hunting. We can add the pattern of selected places for such practice. Both in Pampa and Patagonia, these places coincide with special sectors and lagoon and/or river banks for specific activities such as hunting and prey processing. Among the most outstanding sites we can mention Paso Otero 4 and 5, Campo Laborde, Cerro El Sombrero, Cerro Amigo Oeste, Piedra Museo, where the recurrence of these microenvironments working as fauna trappers and as topographic tramps for lurking and capturing preys are present. Moreover, in both regions there are lithic contexts of projectiles such as spears FTP and triangular of straight base are added to these sites (Nami and Menegaz, 1991; Miotti et al., 1999; Mazzanti and Quintana, 2001; Massone, 2004; Messineo et al., 2009; Flegenheimer et al., 2013; Martínez and Gutiérrez, 2015; Miotti and Terranova, 2015). This evidence is consistent and reliable and suggests that the equid and camelid appropriation is related with strategies of programmed hunting. These strategies may have been 
by ambush and use of special conditions of some continental aquatic landscapes, found only in some sectors of lagoons and streams, where small elevations present in the surroundings could have allowed concealment of the hunters (see works cited above). This argument has a similar pattern as regards the use of landscapes, mammal fauna and strategies of collective hunting between hunter-gatherer societies from different parts of America, from the end of Pleistocene to the end of the 20th century (Speth, 1983; Frison and Todd, 1987; Binford, 1991; Miotti, 1993-96; Miotti et al., 1999, 2004; Martínez, 1999, among others).

However, equids of both species have a lower hunting incidence in Pampean region than in Patagonia. In this last region Hippidion appears represented in numerous sites, being also more numerous and clearer the evidence of chopping and human consumption than in Pampean sites (Miotti and Cattáneo, 2003; Miotti and Salemme, 2005; Marchionni, 2013).

Possibly, as equids are gregarious animals, of open environments and share these with camelids, the hunting strategy of both could have been adjusted well to technology, using the same weapons and lurking forms for their capture. Moreover, in Southern Patagonia it is remarkable that zoomorphic images assigned to horses were represented in several sites such as Cave 6 of Los Toldos, Cave Túnel 1 of La María and possibly their tracks may have been recorded in the petroglyph of Piedra Museo. In this last case, even though their chronological order is discussed (see Carden, 2009 and reference therein) due to the fact that the petroglyphs lean on the stratigraphic layer corresponding to $c a$. 7.7-7.4 years BP (Miotti et al., 2003), the social use of equids is brought into question even for times when equids had already disappeared in both regions. In this case, the persistence of extinct animals in social memory would be similar to that previously referred to for xenarthrans. Thus, the symbolic use of that fauna through collective memory of societies could have moved at least 1000 years the idea of Pleistocenic horses that lived in Patagonian steppes. The last appearance in the Patagonian environment was recorded in $8.5 \mathrm{Ka}$ $\mathrm{BP}$, in the paleontological site Cerro Bombero, in Santa Cruz central plateau (Paunero, 2010).

This form of narrative and transmission, from generation to generation, of the knowledge of environments and beings who were extinct when being materialized in rock art or in ornaments/ offerings, is a symbolic narrative that the ancient settlers may have used for transmitting to their descendants the history of the ancestors who colonized that place with different characteristics and beings from those they knew (Politis and Saunders, 2002; Rockman, 2003; Miotti and Carden, 2007; Miotti et al., 2015). When the scale of information about extinguished or mythic beings and landscapes lasts in wide regions and can be resignified by centuries and millenniums in societies, such as the case of the appropriation of many supernatural and/or natural beings (unicorns, dragons, jaguars), it is then when this is considered as social knowledge and culturally learned (Ingold, 1986; Taçon et al., 1996; Saunders, 1998; Meltzer, 2003).

The evidence of few cut marks in anatomic units of mylodonts is present in few sites, AEP1, El Trébol, Paso Otero 5, and AS 2, remaining as a low signal for supporting the hypothesis of a systematic hunting of these animals. That is why it is more parsimonious to hold the hypothesis of opportunist use (Borrero and Martin, 2012) of any dead animal by non human reasons, and the subsequent attainment of their parts, not for food, but for diverse uses like bones for fuel (Álvarez et al., 2013); or leather. It is significant that in Baño Nuevo-1 cave, dermal bones (osteoderms) could have been associated to the death treatment with the human body wrapping. However, taphonomic and stratigraphic investigations indicate that these bones are not associated to cultural layers (Mena and Reyes, 2001). Similar cases are Fell and Pali Aike, where charred/burnt human remains were covered by large Mylodont bones (Hyslop, 1988). Third similar case and associated to human burials is that of AS2, in Pampa (Salemme, 2014). In these contexts, though, bones do not present cut or human action traces. Meanwhile in El Trébol cave, osteoderms appear burnt and show bearing anthropic cutmarks (Hajduk et al., 2009, 2012; Lezcano et al., 2010). This evidence reinforces the idea that their association to the use of leather by human would be a hypothesis to evaluate.

From the paleontological information of these three sites of the central plateau, it can be inferred that Lujanian stock of xenarthrans, horses and camelids, placed in Bahía Sanguineto (Ameghino, 1880), together with those from Fitz Roy, Puerto Deseado and the only horse individual found in Cerro Bombero, may have been available for the late Pleistocene in the plateau. This information added to that paleo-environmental of the area, mainly palinological (Borromei, 2003; Mancini et al., 2005; Mancini, 2009), supports the hypothesis that this could have been an open grassland steppe, with shrub patches, similar to Pampean region for the same time span.

As regards the archaeological evidence (taxonomic and anatomic abundance) of guanaco, undoubtedly it is the most important species in the sites since the beginning of the human occupation in both regions. Nevertheless, in this group, the social appropriation goes beyond the economic sphere involve that social and imaginary domains, since the artistic representation of these animals appears in several places of Patagonia until late Holocene (Miotti and Carden, 2007 and reference therein).

The zooarchaeological contexts grouped by intervals (Table 3 and Fig. 6) indicate that those of the first interval (16 - $10 \mathrm{Ka} \mathrm{BP)}$ show a greater biodiversity than those of the second interval (9.9-8.7 Ka BP). For this span only horses and Lama gracilis persisted. Besides, during this span, the presence of Lama guanicoe is increased in number of individuals and of represented anatomic parts in all the considered sites.

In this case, the general trend of the first times became a hunting strategy of specification of resources, centered in the most popular species, the guanaco, with few cervid representatives in northern sites of the region, on the other hand, the only survivors of Pleistocenic Lujanian fauna in Patagonia.

The information gathered in this work, resulting from a myriad of sites of Pampa and Patagonia does not allow stating the generalization made by Martínez and Gutiérrez (2011) about the use of guanacos, since this theory is based on the archaeological evidence of a single site: "Remarkably, in one archaeological site (Paso Otero 5, see, mammal record previous of the extinction showed a large exploitation of extinct mammals and a reduced one of guanacos (Lama guanicoe). After the extinction, hunting was concentrated on guanacos and other relatively small mammals. This could be the representation of an opportunistic behaviour that resulted after the extermination of the spectacular fauna of huge mammals that inhabited South America before the entrance of humans. (Martínez and Gutiérrez, 2011, pp. 61).

By the evidence discussed at regional scale we understand that megafauna extinction did not interrupt the social and symbolic use that humans made of these giants in Holocene, and that their extinction did not lead to a more opportunistic use of smaller species, but rather, since the beginning of the human settling in both regions, the food subsistence basis was in guanacos, being the extinguished species of complementary and opportunist use.

As regards hairy xenarthrans, during the first interval it is scarce the representation of individuals and their anatomic parts in the archaeological sites, with which the most feasible hypothesis is that these animals formed part of the colonization landscape of the first humans in the region, but their use would be complementary or 
opportunistic. If there was really a human intention of consumption, this was occasional. Only chopping patterns of these "allegedly preys" were detected in few sites such as Piedra Museo (Marchionni and Vázquez, 2012) and Arroyo Seco 2 (Politis et al., 2014; Gutiérrez and Johnson, 2014). Another use given to bones belonging to these animals was as fuel, as seen in Paso Otero 4 (Gutiérrez et al., 2010; Martínez and Gutiérrez, 2015). There are no artifacts made of these bones what means that this hypothesis of their use as part of technology is even weaker. However, in some cases, the mylodon association of a big deal of dermal little bones as in Cueva Fell, and El Trébol, and large bones used as fuel in Paso Otero 4, may be indicating that these first settlers of Patagonia might have used these animals' leather and bones for different social and symbolic practices.

The coexistence between the first explorers and Pleistocenic megafauna could have been in stages according to different taxa and environmental differences in both regions. In Patagonia (12.5 $\mathrm{Ka} \mathrm{BP}$ ) it would begin 1000 years before and besides it would finish 1000 years before than in Pampa ( $c a .7 \mathrm{ka} \mathrm{BP}$ ). The large carnivores do not have archaeological record in Pampa, whereas in Patagonia, though with a low record, it is considered that they were used somehow by the first settlers (Table 6). The images of great felines are present in rock art and in the zooarchaeological record from the presence of paws and tusks. In Magallanes, Arctotherium sp, Smilodon sp, and a similar genus of xenarthra are also recorded (Mena and Reyes, 2001; Labarca, 2015), the latter with an archaeological record of a paw in the site Túnel of Santa Cruz central plateau (Skarbun et al., 2015).

Even though in Pampa region, the species Panthera onca (jaguar) had a distribution until the beginning of the 20th century, for this region and from the zooarchaeology, we conclude that the extinct subspecies Panthera onca mesembrina was coeval but was not used by the first settlers of this region (Table 6).

Teeth and paws of these felines are pieces of high preservation in the archaeological and paleontological records, as a result, if this species played a role in the cosmovision of the first settlers of both regions, it could be expected that they had been collected by the first settlers, even without ever having had the intention of hunting these carnivores. However, the zooarchaeological evidence of these elements is very fragmented, appearing in three sites so far (Caves Túnel de La María; El Ceibo and Cueva del Medio).

The only representation of a large feline in rock art of cave 6 of $\mathrm{El}$ Ceibo, although it is scarce evidence, supports the hypothesis of a social and symbolic appropriation of these animals, at least for the Patagonian area. However, it must be discarded the idea of economic use, or programmed hunting of these large felines. Both pieces of evidence account for a social knowledge and symbolic use of these animals (Rockman, 2003), which could have remained for many generations in the collective imaginary, even after their extinction. This collective memory may indicate that these animals certainly entered the cosmologic sphere of the first settlers, that is why, their appropriation expressed in images and in tooth and paw recollection would evoke their presence in the social collective of the first hunter-gatherers.

It is worth highlighting that in several societies, from current hunter-gatherers, such as Nukak groups from Amazonia, to Andean state societies (Dillehay and Kaulick, 1984-85; Saunders, 1998), the jaguar figure is conceived as one of a supernatural being with great power. This power could be transferred or granted to people through the possession of paws and tusks or the leather of these animals. Possessing these pieces, in general, did not result from the chasing and systematic hunting of these carnivores, but rather from collecting them after finding dead individuals. In this sense, it is worth thinking about the social importance that a tooth collar acquired, since for manufacturing it, dozens of elements were necessary and long time was spent as it was not frequent to find dead jaguars every day. On the other hand, these collars could have been prestigious artifacts of hereditary type, what means that we can trace a biography (Gosden and Marshall, 1999). This allows inferring that their finding in a definite historic context is the result of a cultural tradition which could have started hundreds of years ago.

The gomphotherid group belonging to immigrant holartic megafauna is scarcely represented in Pampa and Patagonia regions. It is only recorded in Monte Verde site, in the north of Patagonia, (Fig. 1). In the earliest occupational context, the abundance of Cuveronius sp. genus is of a NISP $=268$ specimens, corresponding to a MNI of 1 individual (Dillehay, 1997). The cutmarks and usefulness are mostly represented in task fragments, what allows inferring a human opportunistic profit of any individual found dead, that is why, the hypothesis about programmed hunting of these proboscideans is discarded.

\section{Conclusions}

The extinction event was certainly spectacular. Some authors have referred to it as a mass extinction (Marshall et al., 1984; La Violette, 2011). However, it was not. Coexistence between first human explorers and Pleistocenic megafauna and large mammals was differential in time in each species process. Nonetheless, coexistence remained $c a$. 5000 years since first humans arrived in Pampa and Patagonia. Human/fauna relationships started and finished ca. 1000 years before in Patagonia (Fig. 6).

In Pampa the occurrence of few species of Lujanian stock in archaeological contexts ( $c a$. 7.5 Ka BP) allows us to infer that glyptodonts were economically exploited, and probably also socially and symbolically used for longer time than in Patagonia.

Scouting landscapes (12-11 Ka BP) in Patagonia, and (11-10.5 Ka $\mathrm{BP}$ ) in Pampa had a lot mega mammals and large mammals available for new hunter-gatherer groups. The greatest biodiversity is recorded in Pampa, in Arroyo Seco 2 site (12 taxa), followed by sites in Patagonia, with the greatest records in Cueva Lago Sofía 4 (5 taxa) (Tables 1 and 2).

Colonization landscapes (11-8.5 Ka BP) in Patagonia, and (10.5-7. ka BP) in Pampa had different economic, social and symbolic incidence of the extinct fauna.

In Patagonia region the main resource hunted was Lama guanicoe, meanwhile Hippidion and L. gracilis were complementary, and Ground giant sloths were occasional. Only some parts of Panthera onca and other great carnivores were used, and these parts may have been obtained from finding dead animals but no from hunting.

However, interaction human/animals should have been a high impact on social and symbolic spheres (Table 6). Archaeological record in rock art and daily contexts reinforces this hypothesis.

In Pampa L. guanicoe was the main species exploited, L. gracilis, and ground sloths were occasional and/or complementary resources.

As regards camelids, even though Lama gracilis and Hemiauchenia paradoxa were available in both regions until ca. $9 \mathrm{Ka} \mathrm{BP}$, the evidence of use of both is stronger in the Patagonian region than in that Pampean, where it can be inferred only the coexistence but not the human use.

Thus, those of greater chances of a taxa-human coexistence span were xenarthrans cingulates in Pampa and equids in Patagonia. Therefore, equids are outstanding in Patagonia as economic, social and symbolic resource, whereas the Pampean evidence is even weaker to be able to infer relevance in any of these three aspects in this region. 


\subsection{In short}

What happened when megafauna became extinguished?

Palaeo-environmental aspect generated several consequences in restructuration of climates, biota, and water distribution, producing huge changes for landscapes in both regions. However, from the human point of view, we can say that the changes were economically smaller. In both regions the guanacos were the main faunal resources, however, other species like birds, armadillos, rodents and cervids were used as complementary, and promoted a generalist hunter strategy since the first human occupations.

However, from the social and symbolic appropriation the Pleistocenic giants probably were important beings which after their extinction became myths and legends, remaining among Pampean and Patagonian people long time.

In scientific thought we are in agreement "If those giant Plesitocenic bugs encourage our curiosity, maybe, despite being extinct, they will continue somehow alive just like some hundreds of centuries ago". (Fariña and Vizcaíno, 1995, pp. 97).

\section{Aknowledgments}

We thank colleagues for help provided along the way, Alberto Cione for discussions concerning the Pleistocene mammals at issue in this paper, Darío Hermo, Rafael Suárez and the anonymous referees for valuable comments on the manuscript, and Diego Gobbo for creating the map. This work was done within the framework of the projects PICT-ANCyT-176 and PI-665 UNLP.

\section{Appendix A. Supplementary data}

Supplementary data related to this article can be found at https://doi.org/10.1016/j.quaint.2018.01.004.

\section{References}

Aguerre, A.M., 2003. La Cueva 4 de La Martita y las ocupaciones de 8000 años (Santa Cruz, Argentina). In: Aguerre, A.M. (Ed.), Arqueología y Paleoambiente en la Patagonia Santacruceña Argentina. Talleres Gráficos Nuevo Offset, Buenos Aires, pp. 27-61.

Alberdi, M.T., Leone, G., Tonni, E.P., 1995. Evolución Biológica y Climática de la Región Pampeana Durante los últimos Cinco Millones de Años. Monografías 12 Museo Nacional de Ciencias Naturales, Madrid, p. 423.

Álvarez, M.C., Alcaráz, A., Gutiérrez, M.A., Martínez, G., 2013. Análisis zooarqueológico del sitio Paso Otero 4 (Partido de Necochea, provincia de Buenos Aires, Argentina). Aportes a la discusión de modelos de subsistencia de la región pampeana. Intersecc. Antropol. 14, 383-398.

Ameghino, F., 1880. La Antigüedad del Hombre en el Plata. Imprenta Coni, Buenos Aires.

Barberena, R., Borrazo, K., Rughini, A., Romero, G., Pompei, M., Llano, C., de Porras, M., Durán, V., Stern, C., Re, A., Estrella, D., Forasiepi, A., Fernández, F., Chediak, M., Acuña, L., Gasco, A., Quiroga, M., 2015. Perspectivas arqueológicas para Patagonia Septentrional: sitio Cueva Huenul 1 (Provincia de Neuquén, Argentina). Magallania 43 (1), 1-29.

Binford, L., 1991. A Corporate Caribou Hunt. Documenting the Archaeology of the Past Lifeways. Expedition: the Magazine of the University of Pennsylvania, 33, pp. 33-43, 1.

Bird, J., 1988. Travels and Archaeology in South of Chile. University Iowa Press, Iowa.

Borrero, L., 1990. Fuego-Patagonia bone assemblages and the problem of the guanaco communal hunting. In: Davis, L., Reeves, B. (Eds.), Hunters of the Recent Past. Unwin Hyman, London, pp. 373-399.

Borrero, L.A., Martin, F.M., 2012. Ground sloths and humans in southern FuegoPatagonia: taphonomy and archaeology. World Archaeol. 44 (1), 102-117.

Borrero, L.A., Martin, F.M., Prieto, A., 1997. La Cueva Lago Sofía 4, Última Esperanza: una madriguera de felino del Pleistoceno tardío. Anales del Instituto de la Patagonia. Serie Ciencias Humanas 25, 103-122.

Borromei, A., 2003. Palinology at Piedra Museo locality, Santa Cruz Province, Argentina. In: Miotti, L., Salemme, M., Flegenheimer, N. (Eds.), Where the South Winds Blow: Ancient Evidence of Paleo South Americans. Center for the Studies of the First Americans. A\&M University Press, Texas, pp. 113-120. EE.UU.

Bryan, A., 1978. An overview of paleo-American prehistory from circum-pacific perspective. In: Bryan, A. (Ed.), Early Man in America from a Circum-Pacific Perspective, Department of Anthropology. University of Alberta, Edmonton, pp. 306-327.
Bryan, A., 1986. New Evidences from South American for Early Man Studies. University of Alberta, Edmonton.

Bryan, A., 1995. Disproof of commonly held assumptions relevant to the peopling of the Americas. Curr. Res. Pleistocene 12, 6-8.

Carden, N., 2009. Imágenes a través del tiempo. Arte rupestre y construccion social del paisaje en la Meseta Central de Santa Cruz. Sociedad Argentina de Antropología, Buenos Aires.

Cardich, A., 1987. Arqueología de Los Toldos y El Ceibo (provincia de Santa Cruz, Argentina). Estud. Atacameños 8, 98-117.

Cione, A., Tonni, E., Soibelzon, L., 2003. The broken zig-zag: late Cenozoic large mammals and tortoise extinction in South America. Revista del Museo Argentino de Ciencias Naturales 5 (1), 1-19.

Cione, A., Tonni, E., Soibelzon, L., 2009. Did humans cause the late pleistocene-early Holocene mammalian extinctions in South America in a context of shrinking open areas? In: Haynes, G. (Ed.), American Megafaunal Extinctions at the End of the Pleistocene. Springer Netherlands, pp. 125-144.

Cione, A., Gasparini, G., Soibelzon, E., Soibelzon, L., Tonni, E., 2015. The Great American Biotic Interchange a South American Perspective. Springer, Netherlands.

Cordero, J.A., 2011. Arqueofauna de las ocupaciones tempranas de cueva Traful I, provincia del Neuquen, Argentina. Arqueología 17, 161-194.

Czerwonogora, A., Fariña, R., Tonni, E., 2011. Diet and isotopes of late pleistocene ground sloths: first results for lestodon and glossotherium (Xenarthra, Tardigrada). Neues Jahrbuch für Geologie und Paläontologie 262, 257-266.

De Nigris, M.E., 2004. El Consumo en Grupos Cazadores Recolectores: Un Ejemplo Zooarqueológico de Patagonia Meridional. Sociedad Argentina de Antropología, Buenos Aires.

Dillehay, T., 1997. Monte Verde: A Late Pleistocene Settlement in Chile. The Archaeological Context and Interpretation, Vol. 2. Smithsonian Press, Washington.

Dillehay, T., Kaulick, P., 1984-85. Aproximación Metodológica: el Comportamiento del Jaguar y la Organización Socio-Espacial Humana. Relaciones de la Sociedad Argentina de Antropología XVI, pp. 27-35.

Durán, V., 1986/1987. Estudio tecno-tipológico de los raspadores del sitio El Verano, Cueva 1. Patagonia Centro Meridional, Santa Cruz, Argentina. Anales de Arqueología y Etnología de la Universidad Nacional de Cuyo 41-42, 129-163.

Fariña, R. Vizcaíno, S., 1995. Hace sólo diez mil años. Donde se trata de cómo era la fauna que habitó América del Sur antes de los indios. Editorial Fin de Siglo, Colección Prometeo, Buenos Aires.

Flegenheimer, N., Miotti, L., Mazzia, N., 2013. In: Graf, K., Ketron, C., Waters, M. (Eds.), Rethinking Early Objects and Landscapes in the Southern Cone. Palaeoamerican Odyssey, Santa Fe, pp. 359-376.

Franco, N., Borrero, L., 2003. Chorrillo Malo 2: initial peopling of the upper Santa Cruz basin, Argentina. In: Miotti, L., Salemme, M., Flegenheimer, N. (Eds.), Ancient Evidence for Paleo South Americans: From where the South Winds Blow. Center for the Study of First Americans. Texas A\&M University Press, pp. 149-152.

Franco, N.V., Martucci, M., Ambrústolo, P., Brook, G., Mancini, M.V., Cirigliano, N., 2010. Ocupaciones humanas correspondientes a la transición PleistocenoHoloceno al sur del Macizo del Deseado: el área de La Gruta (provincia de Santa Cruz, Argentina). Relaciones de la Sociedad Argentina de Antropología XXXV 301-308.

Frison, G., Todd, L., 1987. The Horner Site. The Type Site of the Cody Cultural Complex. Academic Press, London, U.K.

Frontini, R., 2012. El aprovechamiento de animales en valles fluviales y lagunas del sur bonaerense durante el Holoceno. Ph.D, Facultad de Filosofía y Letras. Universidad de Buenos Aires, Buenos Aires.

González, A.R., 1974. Arte, Estructura Y Arqueología. Ediciones Nueva Visión, Buenos Aires.

Gosden, Ch, Marshall, Y., 1999. The cultural biography of objects. World Archaeol. 31 (2), 169-178.

Grayson, D., 1984. Quantitative Zooarchaeology. Topics in the Analysis of Archaeological Faunas. Academic Press.

Guilday, J., 1984. Pleistocene extinction and environmental change. In: Martin, P., Klein, R. (Eds.), Quaternary Extinctions a Prehistoric Revolution. The University of Arizona Press, Arizona, pp. 250-258.

Guthrie, R.D., 1984. Mosaics, allelochemics, and nutrients: an ecological theory of late pleistocene megafaunal extinctions. In: Martin, P., Klein, R. (Eds.), Quaternary Extinctions a Prehistoric Revolution. The University of Arizona Press, Arizona, pp. 259-298.

Gutiérrez, M., Johnson, E., 2014. Análisis de los efectos tafonómicos del material óseo faunístico. Interpretaciones sobre los procesos de la formación del sitio. In: Politis, G., Gutiérrez, M., Scabuzzo, C. (Eds.), Estado actual de las Investigaciones en el sitio arqueológico Arroyo Seco 2 (Partido de Tres Arroyos, Provincia de Buenos Aires, Argentina), serie Monográfica n 5 . INCUAPA-CONICET-UNICEN, Olavarría, pp. 97-137.

Gutiérrez, M.A., Martínez, G., Luchsinger, H., Álvarez, M.C., Barros, M.P., 2010. Investigaciones arqueológicas y geoarqueológicas preliminares en el sitio Paso Otero 4 (Partido de Necochea). In: Berón, M., Luna, L., Bonomo, M., Montalvo, C., Aranda, C., Carrera Aizpitarte, M. (Eds.), Mamul Mapü: pasado y presente desde la arqueología pampeana. Libros del Espinillo, Ayacucho, pp. 69-84.

Hajduk, A., Albornoz, A., Lezcano, M., 2009. Nuevas excavaciones en el sitio El Trébol. San Carlos de Bariloche, Provincia de Río Negro. Más sobre los niveles con fauna extinta. In: Problemáticas de la arqueología contemporánea. Universidad Nacional de Río Cuarto, Córdoba, Tomo III, pp. 955-966. 
Hajduk, A., Albornoz, A., Lezcano, M., Arias, P., 2012. The first occupations of the el Trebol site during the pleistocene-holocene transition (nahuel huapí lake, patagonia, Argentina). In: Miotti, L., Salemme, M., Flegenheimer, N., Goebel, T. (Eds.), Southbound. Late Pleistocene Peopling of Latin America. Special Edition Current Researh in the Pleistocene. Center for the Study of the First Americans. Texas A\&M University Press, Texas, pp. 117-120.

Hyslop, J., 1988. Las fronteras estatales extremas del Tawantinsuyu. Proceedings, $45^{\circ}$ Congreso Internacional de Americanistas, Bogotá, Colombia, 1985 ("La Frontera del Estado Inca"). BAR Int. Ser. 442, 35-57. Great Britain.

Ingold, T., 1986. The Appropiation of Nature. Essays on Human Ecology and Social Relations. Manchester University Press, Cambridge.

Labarca, R., 2015. La meso y megafauna terrestre extinta del Pleistoceno de Chile, 63. Publicación Ocasional del Museo Nacional de Historia Natural de Chile, pp. $401-465$.

Labarca, R., Fuentes, F., Mena Larrain, F., 2008. Los conjuntos faunísticos pleistocénicos de cueva las guanacas (región de Aisen, Patagonia chilena): alcances taxonómicos y tafonómicos. Magallania 36 (2), 123-142.

La Violette, P., 2011. Evidence for a solar flare cause of the pleistocene mass extinction. Radiocarbon 53 (2), 303-323.

Lezcano, M.J., Hajduk, A., Albornoz, A.M., 2010. El menú a la carta en el bosque ¿entrada o plato fuerte?: una perspectiva comparada desde la zooarqueología del sitio El Trébol (lago Nahuel Huapi, Pcia. de Río Negro). In: Gutiérrez, M.A., De Nigris, M., Fernández, P.M., Giardina, M., Gil, A.F., Izeta, A., Neme, G., Yacobaccio, H.D. (Eds.), Zooarqueología a Principios del Siglo XXI: Aportes Teóricos, Metodológicos y Casos de Estudio. Ediciones del Espinillo, Buenos Aires, pp. 243-257.

Mancini, V., 2009. Holocene vegetation and climate changes from a peat pollen record of the forest-steppe ecotone, Southwest of Patagonia (Argentina). Quat. Sci. Rev. 28 (15-16), 1490-1497.

Mancini, V., Páez, M.M., Prieto, A.R., 2005. Mid-Holocene paleoenvironments and human occupation in southern South America. Quat. Int. 132 (1), 47-59.

Marchionni, L., 2013. Comparacion de las distintas historias tafonomicas en conjuntos zooarqueologicos provenientes de la Meseta Central de la provincia de Santa Cruz. PhD Facultad de Ciencias Naturales. Universidad Nacional de La Plata, Argentina.

Marchionni, L., Vázquez, M., 2012. New data on exploited pleistocene fauna at Piedra Museo (Central Plateau of Santa Cruz province, Argentina). In: Miotti, L. Salemme, M., Flegenheimer, N., Goebel, T. (Eds.), Southbound: Late Pleistocene Peopling of Latin America. Current Research in the Pleistocene, Center for the Study of the First Americans. Texas A\&M University, Texas, pp. 139-142.

Marshall, L., Hoffstetter, B., Pascual, R., Reig, O., Bombin, M., Mones, A., 1984. Mammals and Stratigraphy: Geochronology of the Continental Mammalbearing Quaternary of South America Palaeovertebrata Mémoire Extraordinaire, pp. 1-76.

Martin, P., 1973. The discovery of America. Science 179, 969-974.

Martin, P., 2005. Twilight of the Mammoths: Ice Age Extinctions and the Rewilding of America. University of California Press, Berkeley, CA.

Martin, F., 2013. Tafonomía y paleoecología de la transición Pleistoceno-Holoceno en Fuego-Patagonia. Interacción entre humanos y carnívoros y su importancia como agentes en la formación del registro fósil. Ediciones de la Universidad de Magallanes, Punta Arenas.

Martínez, G., 1999. Tecnología, subsistencia y asentamiento en el curso medio del río Quequén Grande. Un enfoque arqueológico. PhD, Facultad Ciencias Naturales y Museo. Universidad Nacional de La Plata, La Plata, Argentina.

Martínez, G.A., Osterrieth, M., 2003. The Pleistocene-Holocene stratigraphic record from early archaeological sites in caves and rockshelters of Eastern Tandilia, Pampean Region, Argentina. In: Miotti, L., Salemme, M., Flegenheimer, N. (Eds.), Where the South Winds Blow. Ancient Evidence of Paleo South Americans. Center for the Studies of the First Americans. Texas A\&M University Press, College Station, pp. 63-68.

Martínez, G., Gutiérrez, M.A., 2011. Paso Otero 5: a summary of the interdisciplinary lines of evidence for reconstructing early human occupation and paleoenvironment in the Pampean region, Argentina. In: Vialou, D. (Ed.), Peuplements et Préhistoire de l'Amérique. Muséum National d' Histoire Naturelle. Département de Préhistoire, U.M.R, Paris, pp. 271-284.

Martínez, G.A., Gutiérrez, M.A., 2015. Arqueología del río Quequén Grande Cazadores-recolectores tempranos, cambios ambientales y fauna extinta. Ciencia Hoy 24 (144), 11-18.

Martínez, G., Gutiérrez, M., Messineo, P., Kaufmann, C., Rafuse, D., 2016. Subsistence strategies in Argentina during the late Pleistocene and early Holocene. Quat. Sci. Rev. 144, 51-65.

Massone, M., 2003. Fell 1 hunters' fire hearths in magallanes area by the end of the pleistocene. In: Miotti, L., Salemme, M., Flegenheimer, N. (Eds.), Ancient Evidence for Paleo South Americans: from where the South Winds Blow. Center for the Study of First Americans. Texas A\&M University Press, pp. 153-159.

Massone, M., 2004. Los Cazadores después del Hielo. Colección de Antropología 7, Centro de Investigación Barros Arana. Ediciones de la DIBAM, Santiago.

Mazzanti, D., 1999. Ocupaciones humanas tempranas en Sierras La Vigilancia y Laguna La Brava, Tandilia Oriental (Provincia de Buenos Aires). In: XII Congreso Nacional de Arqueología Argentina, La Plata, vol. III, pp. 149-155.

Mazzanti, D., Quintana, C., 2001. Cueva Tixi: Cazadores y recolectores de las sierras de Tandilia oriental (Publicacion especial). Laboratorio de Arqueología, Universidad Nacional de Mar del Plata. Facultad de Humanidades, Mar del Plata.

Mazzanti, D., Martínez, G., Colobig, M., Zucol, A., Passeggi, E., Brea, M., Bonnat, G.F., Hassan, G., Soria, J., Vera, J., Quintana, C., 2013. Avances en los estudios arqueológicos, geoarqueológicos y paleoambientales en las sierras orientales de Tandilia. Resultados preliminares de los sitios Alero El Mirador y Abrigo La Grieta. Revista del Museo de La Plata. Antropologi 13, 59-66.

Mazzia, N., 2011. Lugares y paisajes de cazadores-recolectores en la Pampa bonaerense. Cambios y continuidades durante el Pleistoceno final-Holoceno. Ph.D. Facultad de Ciencias Naturales y Museo, Universidad Nacional de La Plata. La Plata.

Mc Culloch, R., Bentley, M.J., Purves, R.S., Hulton, N.R., Sugden, D.E. Clapperton, C.M., 2000. Climatic inferences from glacial and paleoecological evidence at the last glacial termination, southern South America. J. Quat. Sci. 15 409-417.

Meltzer, D., 2003. Lessons in landscape learning. In: Rockman, M., Steele, J. (Eds.), Colonization of Unfamiliar Landscapes. The Archaeology of Adaptation. Routledge, Nueva York, pp. 222-241.

Mena, F., Reyes, O., 2001. Montículos y cuevas funerarias en Patagonia: una visión desde cueva Baño nuevo-1, XI región. Chungará 33, 21-30.

Mena, F., Reyes, O., Stafford Jr., ThW., Southon, J., 2003. Early human remains from Baño Nuevo-1 cave, central patagonian andes, Chile. Quat. Int. 109-110 $113-121$.

Mengoni Goñalons, G.L., 1999. Cazadores de guanacos de la estepa patagónica. Sociedad Argentina de Antropología, Buenos Aires.

Mengoni Goñalons, G.L., Silveira, M.J., 1976. Análisis e interpretación de los restos faunísticos de la Cueva de las Manos Estancia Alto Río Pinturas. Relaciones de la Sociedad Argentina de Antropología 10, 261-270.

Mera, M.R., García, P., 2004. Alero Marifilo-1. Ocupación Holoceno temprana en la costa del Lago Calafquén (X Región - Chile). In: Civalero, M., Fernández, P., Guraieb, A. (Eds.), (comp.), Contra Viento y Marea. Instituto Nacional de Antropología y Pensamiento Latinoamericano, Buenos Aires, pp. 249-262.

Messineo, P., Gutiérrez, M., Politis, G., 2009. Las primeras poblaciones indígenas de la región. In: Endere, M.L., Prado, J.L. (Eds.), Patrimonio, ciencia y comunidad. Un abordaje preliminar en los partidos de Azul, Olavarría y Tandil, INCUAPA, Olavarría, pp. 143-165.

Metcalf, J.L., Turney, C., Barnett, R., Martin, F., Bray, S.C., Vilstrup, J.T., Orlando, L., Salas-Gismondi, $R$, Loponte, $\mathrm{D}$, Medina, $\mathrm{M}$, De Nigris, $\mathrm{M}$., Civalero, $\mathrm{T}$. Fernández, P.M., Gasco, A., Duran, V., Seymour, K.L., Otaola, C., Gil, A., Paunero, R., Prevosti, F.J., Bradshaw, C.J.A., Wheeler, J.C., Borrero, L., Austin, J.J., Cooper, A., 2016. Synergistic roles of climate warming and human occupation in Patagonian megafaunal extinctions during the Last Deglaciation. Science Advances 2, 1-8. https://doi.org/10.1126/sciadv.1501682.

Miotti, L., 1991. Las manifestaciones rupestres de Santa Cruz, Argentina. In: Podestá, M., Hernández Llosas, M.I., Renard de Coquet, S. (Eds.), El Arte Rupestre en la Arqueología contemporánea. FECIC, Buenos Aires, pp. 132-139.

Miotti, L., 1993-96. Piedra Museo (Santa Cruz): nuevos datos para el debate de la ocupación Pleistocénica en Patagonia. In: Gómez Otero, J. (Ed.), Arqueología, Sólo Patagonia. Centro Nacional Patagónico Y CONICET. Puerto Madryn, pp. 27-38.

Miotti, L., 1998. Zooarqueología de la meseta central y costa de la provincia de Santa Cruz: Un enfoque de las estrategias adaptativas aborígenes y los paleoambientes. Museo Municipal de Historia Natural de San Rafael, San Rafael.

Miotti, L., 2003. A paradox for building images of the colonization of the new world In: Miotti, L., Salemme, M. (Eds.), South America, Long and Winding Roads for the First Americans at the Pleistocene/Holocene Transition. Quaternary International vols. 109-110, pp. 147-173.

Miotti, L., 2008. Household and sacred landscapes among Holocene huntergatherers of Patagonia's Central Plateau. Before Farming 3, 5-44.

Miotti, L., 2012. El uso de los recursos faunísticos entre los cazadores-recolectores de Patagonia: tendencias espacio/temporales de las estrategias durante e Holoceno. La Potenciación de los recursos entre los cazadores-recolectores de Patagonia. Factores, Procesos e implicancias arqueológicas. ARCHAEOFAUNA 21, 137-160.

Miotti, L., Salemme, M., 1999. Biodiversity, taxonomic richness and generalistspecialists economical systems in Pampa and patagonia regions, southern south America. Quat. Int. 53-54, 53-68.

Miotti, L., Cattáneo, R., 2003. Variation in the strategies of the lithic production and faunal exploitation during Pleistocene/Holocene Transition at Piedra Museo and surrounding region. In: Miotti, L., Salemme, M., Flegenheimer, N. (Eds.), Where the South Winds Blow: Ancient Evidence for Paleo South Americans. Center for the Study of the First Americans. University of Texas A\&M, USA, pp. 105-112.

Miotti, L., Salemme, M. 2004. Poblamiento, movilidad y territorios entre las sociedades cazadoras-recolectoras de Patagonia: cambios desde la transición Pleistoceno/Holoceno al Holoceno medio. Complutum 15, 177-206.

Miotti, L., Salemme, M., 2005. Hunting and butchering events at late pleistocene and early Holocene in Piedra Museo (patagonia, southernmost south America) In: Bonnichsen, R. (Ed.), Paleoamerican Prehistory: Colonization Models, Biological Populations, and Human Adaptations. Center for the Study of the First Americans. University of Texas A\&M, USA., pp. 141-151

Miotti, L., Carden, N., 2007. The relationships of rock art and archaeofaunas in the central patagonian plateau. In: Gutiérrez, M.A. (Ed.), Thaphonomy and Zooarchaeology in Argentina. British Archaeological Reports (BAR), U.K, pp. 203-218.

Miotti, L., Marchionni, L., 2012. Tools beyond Stones: bone, a non-traditional raw material in continental Patagonia. In: Choyke, A., O'Connors, S. (Eds.), From These Bare Bones: Raw and Worked Osseous Materials. Oxbow Books, Oxford UK, pp. 116-126.

Miotti, L., Marchionni, L., 2014. Autopodios de guanacos en sitios arqueológicos 
equifinalidad entre lo palatable y lo preservado. Revista Chilena de Arqueología 29 (1), 122-129.

Miotti, L., Terranova, E., 2015. A hill plenty of points in terra incognita from Patagonia: notes and reflections for discussing the way and tempo of the initial peopling. PaleoAmerica 1 (2), 181-196.

Miotti, L., Vázquez, M., Hermo, D., 1999. Piedra Museo un Yamnagoo Pleistocénico en la Colonización de la Meseta de Santa Cruz. El estudio de la Arqueofauna. In: Goñi, R. (Ed.), Soplando en el Viento. Universidad Nacional del ComahueInstituto Nacional de Antropología y Pensamiento Latinoamericano. NeuquénBuenos Aires, pp. 113-136.

Miotti, L., Salemme, M., Rabassa, J., 2003. Radiocarbon chronology at Piedra Museo locality. In: Miotti, L., Salemme, M., Flegenheimer, N. (Eds.), Where the South Winds Blow: Ancient Evidence of Paleo South Americans. Center for the Studies of the First Americans-Texas A \& M. University Press, Texas, pp. 99-104.

Miotti, L., Salemme, M., Hermo, D., Magnin, L., Rabassa, J., 2004. Yamnago 137 años después: otro lenguaje para la misma región. In: Civalero, M.T., Fernández, P. Guraieb, A. (Eds.), Contra Viento y Marea: Arqueología de Patagonia. Instituto Nacional de Antropología y Pensamiento Latinoamericano y Sociedad Argentina de Antropología, Buenos Aires. pp., pp. 775-796

Miotti, L., Hermo, D., Magnin, L., Carden, N., Marchionni, L., Terranova, E. Mosquera, B., Salemme, M., 2007. Resolución arqueológica en la Cueva Maripe (Santa Cruz, Argentina). In: Morello, F., Martinic, M., Prieto, A., Bahamonde, G. (Eds.), Arqueología de Fuego-Patagonia: Levantando piedras, desenterrando huesos...y develando arcanos. Ediciones CEQUA. Punta Arenas, pp. 555-569.

Miotti, L., Marchionni, L., Mosquera, B., Hermo, D., Ceraso, A., 2014. Fechados radiocarbónicos y delimitación temporal de los conjuntos arqueológicos de Cueva Maripe, Santa Cruz (Argentina). Relaciones 39 (2), 509-537.

Miotti, L., Hermo, D., Terranova, E., Blanco, R., 2015. Edenes en el desierto. Señales de caminos y lugares en la historia de la colonización de patagonia argentina. Antipodas 23, 161-185.

Morello, F., Contreras, L., San Román, M., 1999. La localidad Marazzi y el sitio arqueológico Marazzi I, una reevaluación. Anales del Instituto de la Patagonia. Serie Ciencias Humanas 27, 183-197.

Nami, H.G., Menegaz, A., 1991. Cueva del Medio, aportes para el conocimiento de la diversidad faunística hacia el Pleistoceno Holoceno en Patagonia Austral. Anales del Instituto de la Patagonia. Serie Ciencias Sociales 20, 125-133.

Nami, H., Nakamura, T., 1995. Cronología radiocarbónica con AMS sobre muestras de huesos procedentes del sitio Cueva del Medio (Última Esperanza, Chile). An. Inst. Patagonia 23, 125-133.

Paunero, R., 2000. Localidad arqueológica cerro Tres Tetas. In: Miotti, L., Paunero, R., Salemme, M., Cattáneo, R. (Eds.), Guía de Campo de la visita a las Localidades arqueológicas. Taller Internacional "La colonización del Sur de América durante la transición Pleistoceno/Holoceno". Servicoop, La Plata, pp. 89-100.

Paunero, R., 2003. The cerro Tres Tetas (C3T) locality in the Central Plateau of Santa Cruz, Argentina. In: Miotti, L., Salemme, M., Flegenheimer, N. (Eds.), Where the South Winds Blow: Ancient Evidence of Paleo South Americans. Center for the Studies of the First Americans. A \& M University Press, Texas, pp. 33-40.

Paunero, R., 2010. La extinción de Hippidion saldiasi y su relación con el paleoambiente y los grupos humanos que colonizaron Patagonia. Nuevos datos provenientes de Cerro Bombero, Santa Cruz. In: Gutiérrez, M.A., De Nigris, M. Fernández, P.M., Giardina, M., Gil, A., Izeta, A., Neme, G., Yacobaccio, H. (Eds.), Zooarqueología a principios del siglo XXI: Aportes teóricos, metodológicos y casos de estudio. Ediciones del Espinillo, Buenos Aires, pp. 297-306.

Paunero, R., Frank, A., Skarbun, F., Rosales, G., Cueto, M., Zapata, G., Paunero, M. Lunazzi, N., Del Giorgio, M., 2007. Investigaciones Arqueológicas en Sitio Casa Del Minero 1, Estancia La María, Meseta Central de Santa Cruz. In: Morello, F., Martinic, M., Prieto, A., Bahamonde, G. (Eds.), Arqueología de Fuego-Patagonia: Levantando piedras, desenterrando huesos...y develando arcanos". Ediciones CEQUA, Punta Arenas, pp. 577-588.

Paunero, R., Paunero, M., Ramos, D., 2010. Artefactos óseos en componentes del Pleistoceno final de las localidades La María y Cerro Tres Tetas, Santa Cruz, Argentina. In: Gutiérrez, M.A., De Nigris, M., Fernández, P.M., Giardina, M., Gil, A., Izeta, A., Neme, G., Yacobaccio, H. (Eds.), Zooarqueología a principios de siglo XXI: Aportes teóricos, metodológicos y casos de estudio. Ediciones del Espinillo, Buenos Aires, pp. 459-466.

Politis, G.G., 2014. Introductión. In: Politis, G., Gutiérrez, M., Scabuzzo, C. (Eds.), Estado actual de las Investigaciones en el sitio arqueológico Arroyo Seco 2 (Partido de Tres Arroyos, Provincia de Buenos Aires, Argentina). Serie Monográfica $n^{\circ}$ 5. INCUAPA-CONICET-UNICEN. Olavarría, pp. 11-28.

Politis, G.G., Gutiérrez, M., 1998. Gliptodontes y cazadores-recolectores de la región pampeana (Argentina). Lat. Am. Antiq. 9, 111-134.

Politis, G.G., Madrid, P., 2001. Arqueología pampeana: estado actual y perspectivas.
In: Berberián, E., Nilsen, A. (Eds.), Historia Argentina Prehispánica 2. Ediciones Brujas, Córdoba, pp. 737-814.

Politis, G.G., Saunders, N., 2002. Archaeological correlates of ideological activity: food taboos and spirit-animals in an Amazonian hunter-gatherer society. In: Miracle, P., Milner, N. (Eds.), Consuming Passions: Archaeological Studies of Material Culture. McDonald Institute, Cambridge, pp. 113-130.

Politis, G.G., Messineo, P.G., 2008. The Campo Laborde site: new evidence for the Holocene survival of Pleistocene megafauna in the Argentine pampas. Quat. Int. 191, 98-114.

Politis, G., Messineo, P., Kaufmann, C., 2004. El poblamiento temprano de las llanuras pampeanas de Argentina y Uruguay. Complutum 15, 207-224.

Politis, G., Messineo, P., González, M., Alvarez, M., Favier Dubois, C., 2012. Primeros resultados de las investigaciones en el sitio Laguna de los Pampas (partido de Lincoln, provincia de Buenos Aires). Relaciones XXXVII (2), 463-472.

Politis, G., Gutiérrez, M., Scabuzzo, C., 2014. Estado Actual de las investigaciones en el sitio Arroyo Seco 2 (Partido de Tres Arroyos, Provincia de Buenos Aires, Argentina). Serie Monográgica ${ }^{\circ}$ 5. INQUAPA- CONICET. Universidad Nacional del Centro de la Provincia de Buenos Aires, Olavarría.

Politis, G.G., Gutiérrez, M.A., Rafuse, D.J., Blasi, A., 2016. The arrival of Homo sapiens into the southern Cone at 14,000 Years ago. PLoS One 11. https://doi.org/ 10.1371/journal.pone.0162870 e0162870.

Pompei, M., Barberena, R., de Porras, M.E., Borrazo, K., Rughini, E., Gil, A., 2012. Late quaternary ecosystems and humans in northern patagonia: new results from cueva Huenul 1 (Neuquén, Argentina). In: Miotti, L.M., Flegenheimer, N., Salemme, M., Goebel, T. (Eds.), Southbound. Late Pleistocene Peopling of Latin America. Special Edition Current Researh in the Pleistocene, pp. 187-190.

Prado, J.L., Martinez-Maza, C., Alberdi, M.T., 2015. Megafauna extinction in South America: a new chronology for the Argentine pampas. Palaeogeogr. Palaeoclimatol. Palaeoecol. 425, 41-49. https://doi.org/10.1016/j.palaeo.2015.02.026.

Quintana, C. Valverde, F., Albino, A., 2003. Registro de fauna de Cueva El Abra Tandilia Oriental Provincia de Buenos Aires. In: XIII Congreso Nacional de Arqueología Argentina; Córdoba, pp. 317-324.

Rabassa, J., 2008. Late Cenozoic glaciations in Patagonia and Tierra del Fuego. In: Rabassa, J. (Ed.), The late Cenozoic of Patagonia and Tierra del Fuego. Elsevier, New York, pp. 151-204.

Reichel-Dolmatoff, G., 1975. The Shaman and the Jaguar: an Study of Narcotic Drugs Among the Indians of Colombia. Temple University Press, Philadelphia.

Rockman, M., 2003. Knowledge and learning in the archaeology of colonization. In: Rockman, M., Steele, J. (Eds.), Colonization of Unfamiliar Landscapes. The Archaeology of Adaptation, Routledge, Londres, pp. 3-24.

Salemme, M., 2014. Zooarqueología y paleoambientes. In: Politis, G., Gutiérrez, M., Scabuzzo, C. (Eds.), Estado actual de las Investigaciones en el sitio arqueológico Arroyo Seco 2 (Partido de Tres Arroyos, Provincia de Buenos Aires, Argentina). Serie Monográfica $n^{\circ}$ 5, INCUAPA-CONICET. Universidad Nacional del Centro de la Provincia de Buenos Aires, Olavarría, pp. 67-96.

Salemme, M., Miotti, L., 2008. Archaeological hunter-gatherer landscapes since the latest pleistocene in fuego- patagonia. In: Rabassa, J. (Ed.), Late Cenozoic of Patagonia and Tierra Del Fuego. Elsevier, Nueva York, pp. 437-483.

Sanguinetti, A., 1976. Excavaciones prehistóricas en la cueva de "Las Buitreras" (provincia de Santa Cruz). Relaciones XI 271-292.

Saunders, N., 1998. Introduction. Icons of power. In: Saunders, N. (Ed.), Icons of Power: Feline Symbolism in the Americas. Routledge London \& New York, pp. $1-10$.

Sellards, E., Evans, G., Meade, G., 1947. Fossil bison and associated artifacts from Plainview, Texas, with description of artifacts by Alex Kreiger. Bulletin. Geological Society of America 58, 927-954.

Silveira, M., 1979. Análisis e Interpretación de Los Restos Faunísticos de la Cueva Grande del Arroyo Feo (Provincia de Santa Cruz). Relaciones de la Sociedad Argentina de Antropología XIII, pp. 229-253.

Skarbun, F., Cueto, M., Frank, A., Paunero, R., 2015. Producción, consumo y espacialidad en cueva Túnel, meseta central de Santa Cruz, Argentina. Chungará 47 (1), 85-99.

Speth, J.D., 1983. Bison Kills and Bone Counts. University of Chicago press, Chicago.

Taçon, P., Wilson, M., Chippindale, C., 1996. Birth of the rainbow serpent in Arnhem land rock art and oral history. Archaeol. Ocean. 31 (3), 103-124.

Tonni, E., Carlini, A., 2008. Chapter 13: neogene vertebrates from Argentine Patagonia: their relationship with the most significant climatic changes. In: Rabassa, J. (Ed.), Late Cenozoic of Patagonia and Tierra del Fuego. Elsevier, New York, pp. 269-284.

Wormington, H.M., 1957. In: Ancient Man in North America. Denver Museum of Natural History Popular Series $N^{\circ} 4$, fourth ed. Denver. 